\title{
Opportunistic earnings management or performance-related effects? Evidence from dividend-paying firms
}

\begin{abstract}
We propose that much of the variation in standard accruals and real-activities earnings management metrics can be explained by firms' performance trajectories. We test our proposition using dividend change as a natural setting that distinguishes high from low performance trajectory firms. Consistent with our proposition, we find that standard earnings management metrics have a stronger relation with performance trajectories than unexpected earnings at which firms' earnings management activities are supposedly targeted. Additionally, we find that firms with higher values of earnings management metrics, i.e., firms that appear to manage earnings to a greater extent, are more likely to increase their dividends; and standard earnings management metrics are unimportant in explaining changes in firm value around dividend change announcements. These results are consistent with the notion that applying standard earnings management metrics without taking performance trajectories into account can result in researchers mistaking managers' efforts to increase firm value with evidence of earnings management.
\end{abstract}

JEL Classification: G30, G35, M41

Keywords: Accruals Earnings Management, Real-activities Earnings Management, Dividend Changes, Performance Trajectory, Multiperiod Performance

Data Availability: Data is available from public sources identified in the paper 


\section{Opportunistic earnings management or performance-related effects? Evidence from dividend-paying firms}

\section{Introduction}

We propose that studies that fail to fully consider how performance trajectory (multiperiod performance) affects firms' activities will identify deviations of discretionary accruals and real activities from subindustry averages as opportunistic too frequently. Using dividend change as a natural setting that distinguishes high from low performance trajectory firms, we show that much of the variation in real activities can be explained by firms' performance trajectories. Previous research has found a positive correlation between earnings management and past performance (Kothari, Leone and Wasley, 2005; Hribar and Nichols, 2007; and Cohen, Pandit, Wasley and Zach, 2016). We extend these findings and show that earnings management metrics are more closely related to firm performance trajectory than the unexpected earnings at which firms' smoothing activities are supposedly targeted. ${ }^{1}$

Dividend-paying firms make a joint decision to smooth their earnings and dividends as they pursue complementary objectives. These include meeting their earnings and dividend per share targets while also capturing the positive valuation effects associated with reporting smoother earnings and dividends over time (Daniel, Denis and Naveen, 2008; Liu and Espahbodi, 2014). For example, more persistent, low-volatility earnings are viewed as higher quality based on their superior informativeness and predictability (Dechow, Weili and Schrand, 2010). Companies reporting smoother earnings also have lower costs of equity and debt capital

\footnotetext{
${ }^{1}$ Collins, Pungaliya and Vijh (2016) control for a firm's forward-looking growth (e.g., market-to-book ratio, fourquarter ahead sales growth, and analysts' consensus forecast of long-term earnings growth) when estimating abnormal accruals in a quarterly setting. Rather than revising the models to estimate abnormal accruals/real-activity earnings management, which assumes that specific variables such as market-to-book ratio are the relevant omitted variables, we focus on a specific corporate event (i.e., dividend changes) in which expected future performance alone may drive conventional measures of earnings management. We realize that our results do not allow us to completely rule out opportunistic earnings management. However, they clearly reveal problems with the standard earnings management metrics even when past performance is included in the expectation models.
} 
(Francis, LaFond, Olsson and Schipper, 2004 and 2005). These attributes support higher firm valuation. Changes in dividend levels are also positively related to firm profitability and value, and companies with smoother dividend streams are considered to have higher quality, more informative earnings (Skinner and Soltes, 2011).

Additionally, earnings management is usually measured as a single-period activity, despite survey evidence that indicates managers smooth both earnings and dividends across fiscal periods (Graham, Harvey and Rajgopal, 2005 and Brav, Graham, Harvey and Michaely, 2005). CFO survey responses indicate most inter-period smoothing is accomplished by delaying or accelerating real activities, instead of via year-end adjustments to accrual accounts, which is the focus of much of the earnings management literature (Dichev, Graham, Harvey and Rajgopal, 2013). Firms also make comparable tradeoffs as they strive to meet or beat the levels of EPS and DPS expected by investors. Companies postpone investments in value-increasing projects, lay off employees, sell assets, borrow heavily, and decrease spending on advertising, maintenance, and research and development to meet their EPS and DPS goals (Graham, et al. 2005 and Brav et al., 2005). These findings suggest that earnings and dividend smoothing are complementary multiperiod activities that are related to firm performance trajectory.

Prior research proposes that taking a multiperiod, performance-based perspective will lead to alternative interpretations of firms' earnings management activities (Dechow, et al., 2010). Moreover, standard measures of earnings management may not be sufficiently subtle to identify accounting practices that support multiple objectives, such as meeting EPS and DPS targets while reporting smooth streams of earnings and dividends over time. This idea is wellexpressed by one CFO's response to a Dichev, et al. (2013) survey question: "... distinguishing between business-driven economic reasons to cut spending vs. opportunistic cuts aimed at hitting 
earnings targets is difficult for an outside analyst" (p. 29). We argue that if professional analysts find it difficult to draw such distinctions, models based mainly on deviations from subindustry averages will confound performance-driven accounting activities with evidence of opportunistic earnings management, particularly when there are substantial differences in performance across companies.

Before testing our formal hypotheses, we establish that dividend changes reflect information regarding firm performance trajectory. For each dividend announcement event, we sort our sample of firms into three groups based on the percentage change in dividends (decreasers, small increasers and large increasers), rather than one of the earnings-based performance metrics used in previous research, such as pre-managed earnings changes (e.g., Daniel et al., 2008 and Liu and Espahbodi, 2014). We find that firms announcing the most positive (negative) percentage change in dividends at time zero are on the highest (lowest) performance trajectory (spanning years -3 to +3 relative to the announcement), as evidenced by faster (slower) growth in revenues, profits, dividends, cash flows, capital expenditures (CAPEX), and selling and administrative expenses (SG\&A). These findings are consistent with the idea that dividend changes are valid multiperiod performance signals.

Following from our finding that dividend changes are valid multiperiod performance signals, the remainder of this study focuses on testing three hypotheses (developed in the following section) regarding the earnings management of dividend-paying firms. Our first two hypotheses test whether standard earnings management metrics are significantly related to firm performance trajectory, measured as the percentage change in a firm's annual dividends. Our third hypothesis follows from signaling theory predictions that dividend changes provide 
investors with information regarding firm value, and tests our proposition that firms' performance goals take precedence over their earnings management activities.

We test our first hypothesis by investigating the key drivers of earnings management for dividend-paying firms. We model various real and accruals-based earnings management metrics as a function of firms' most recent dividend change and earnings surprise. We control for factors thought to affect firms' incentives to manage earnings and for differences in the life-cycle and financial characteristics of dividend-paying firms. The results show that conventional measures of earnings management have a stronger statistical relation with dividend changes than with unexpected earnings, which is consistent with the idea that earnings management metrics reveal more information about firm performance trajectory than about active attempts to manage earnings.

We test our second hypothesis by modeling the probability that a firm will increase its dividend, controlling for the same life-cycle and financial factors as in the earnings management regressions described above. We find that the probability that a firm increases its dividends increases with the extent of upward real earnings management. We also find that firms that have higher growth in capital expenditures — which would be expected from firms on highperformance trajectories — are more likely to increase their dividends. These findings provide further support for the idea that standard earnings management metrics reflect information about companies' performance trajectory and their ability to increase (or need to decrease) dividends.

Finally, to test our third hypothesis, we investigate the relation between dividend changes and standard earnings management metrics and firm value. Specifically, we regress the 3-day excess return around the dividend change announcement on the percentage change in dividends per share, various measures of earnings management, and life-cycle and financial characteristic 
control variables. We find that the percentage change in dividends is significantly related to the announcement period return, with all the earnings management metrics being insignificant. In addition to confirming the well-established view that changes in dividends convey information to investors, we find that the activities used to smooth earnings and dividends, typically classified as earnings management, have no effect on firm value after controlling for the degree to which dividend-paying firms are able (or find it necessary) to change their dividend level. These results suggest investors focus more on firm performance than the smoothing activities that contributed to the firm's ability (or necessity) to change the dividend.

Our study makes several contributions to the literature, both conceptual and empirical. We identify similarities between the classic explanations for earnings and dividends, especially those related to cash flow signaling and agency issues, and use these to motivate our study. We show how taking a multiperiod perspective suggests that firm performance trajectory influences standard earnings management metrics, and introduce alternative interpretations of these metrics. We also present empirical evidence consistent with the ideas that: (1) standard measures of earnings management are more closely related to dividend changes than unexpected earnings, and thus reflect information regarding multiperiod firm performance; (2) although firms that change their dividend level by larger amounts appear to manage earnings to a greater extent, it is more plausible that much of the differences in earnings management metrics are driven by differences in firm performance trajectory; and (3) dividend change announcements convey more value-relevant information to investors than firms' apparent earnings management activities. Additionally, our results confirm the validity of the suggestions of Dechow, et al. (2010) that analyzing firms' earnings management from a multiperiod, performance-based perspective would yield additional insights regarding the relation between earnings management and earnings 
quality. Our findings are also consistent with recent research that shows accruals earnings management among dividend-paying firms may be less prevalent than previously thought. For example, He, Ng, Zaiats and Zhang (2017) find that dividend-paying firms are less likely to engage in accruals-based earnings management than non-payers, and Kim, Lee and Lie (2017) find that firms facing dividend constraints are more likely to reduce dividends than manage earnings to avoid dividend cuts. A promising direction for future research would be investigating if the relation between firm performance trajectory and standard earnings management metrics generalizes to all firms, including those that do not pay dividends.

The remainder of the paper is organized as follows: section 2 presents our review of the relevant literature and hypotheses; section 3 discusses our data sources and methodology; section 4 presents our empirical results; and section 5 contains our summary and conclusions.

\section{Literature Review, Motivation and Hypotheses}

We identify various factors that contribute to the prevalence of earnings management being overstated in the academic literature. Among these are the dual imperatives to report smooth streams of high quality earnings over time while adhering to the principle of faithful representation; the tendency to measure earnings management as a single-period activity; and the failure to fully account for performance when measuring firms' earnings management activities. We also identify similarities between the classic explanations for earnings and dividends, especially those related to cash flow signaling and agency issues, and use these to motivate the idea that, for dividend-paying firms, earnings and dividend smoothing are interrelated multiperiod activities. Finally, we show how taking a multiperiod perspective suggests that firms' performance trajectories influence standard earnings management metrics, and introduce alternative interpretations of these metrics that lead to our hypotheses. 


\subsection{Faithful representation, Earnings Quality, and the Equilibrium Level of Earnings}

\section{Management}

Markets prize smoother earnings and consider them to be higher quality, as less volatile earnings stream are more informative and predictable. While earnings "smoothing" refers to the minor adjustments managers make to enhance the informativeness and predictability of reported profits, other related terms are earnings "management" and "manipulation," which connote deliberately misstating earnings to misinform users. A large body of academic literature focuses on concerns that earnings management is pervasive and frequently implemented to misrepresent profits, based on the implicit assumption that almost all firms are managing to report higher earnings, rather than achieving smooth earnings as an outcome of a properly-applied accrual system (Dechow, et al., 2010). This is contrary to Dichev, et al. (2013) finding that approximately 40 percent of earnings management activity is deliberately income-decreasing. ${ }^{2}$

If the main goal is to report high-quality earnings, accountants' efforts to create financial statements that are more "decision-useful" (which is facilitated by smoother, less volatile earnings) naturally lead to some non-zero level of earnings management. ${ }^{3}$ On the other hand, the principle of faithful representation requires strict adherence to recording transactions in a way that depicts their true economic substance. From this perspective, many aberrations from accounting rules appear to be not just earnings smoothing but outright management, which

\footnotetext{
${ }^{2}$ Liu and Espahbodi (2014) also find that, on average, dividend-paying firms with positive pre-managed earnings changes manage earnings downward.

${ }^{3}$ A related line of research suggests that managers may engage in both accruals and real earnings management activities to convey management private information about firms' superior future performance and signaling firm value via examining the subsequent operating and market performance of firms identified to be engaged in either accruals or real earnings management activities. For example, research by Sankar and Subramanyam (2001) and Perotti and Windisch (2017) suggests that firms may manage earnings to communicate favorable private information about their future performance. Firms engaging in real earnings management activities demonstrate superior operating and stock performance than those that do not engage in such activities (Gunny, 2010). It should be noted that this line of research assumes that standards measures of earnings management accurately identifies companies that manage earnings.
} 
carries the negative connotation that these choices are designed to misstate profitability and/or confound investors' perceptions regarding the market value of the firm.

We argue that the competing imperatives of faithful representation and earnings quality often induce the appearance of earnings management. The earnings management literature identifies a multiperiod reversal in smoothing activities as high levels of earnings management in one period naturally lead to reversals in subsequent periods. For example, previous studies describe how financially distressed firms take "big baths" (report as much bad news in one fiscal period as possible) and financially successful firms use discretionary activities to fund "cookie jars" for future periods (e.g., Healy and Wahlen, 1999 and Kirschenheiter and Melumad, 2002).

The key issue is whether the reversal in smoothing activities is mainly a natural outcome of accrual accounting or opportunistic earnings management. Hansen (1996) examines the timeseries properties of discretionary accruals using five different models and finds no evidence of managerial opportunism. Other researchers employ modeling assumptions that lead to the conclusion that managers' incentives to manipulate earnings are contracted away in equilibrium (e.g., DeMarzo and Fishman, 2007 and Edmans, 2009). The results of these studies suggest the equilibrium level of earnings management may be close to zero.

Another stream of research asserts that a nonzero level of earnings management is inevitable in a practical world concerned with factors that affect firm value, including reporting smooth, high quality streams of earnings over time. In particular, the incentive compensation of CEOs and CFOs and the duration of CEO tenure have been identified as factors affecting firms' earnings management activities (Bergstresser and Philippon, 2006; Jiang, Petroni and Wang, 2010; Ali and Zhang, 2015). Dutta and Fan (2014) further examine the relation between managerial incentives and earnings management. They model earnings management as a 
naturally-arising phenomenon on an equilibrium path that leads to the "highest quality" accounting statements firms can produce. The managerial compensation contract that maximizes firm value results in some earnings management. These findings were anticipated by Dye (1988): ". . . if shareholders wish managers to exert some nontrivial effort level, they must tolerate some earnings management" [p. 200]. Crocker and Slemrod (2007) also conclude that ". . contracts contingent on reported earnings cannot provide managers with the incentive both to maximize profits and to report those profits honestly. As a result, some degree of earnings management must be tolerated" [p. 698].

Fischer and Verrecchia (2000) note that the costs of manipulating reported earnings can include "... the manager's litigation risks, psychic costs, or reputation costs of biasing a report" [p. 232]. Dutta and Fan (2014) assume that these costs are borne by managers, which places a natural limit on reporting discretion. Another key assumption of the Dutta and Fan (2014) model is that the manager faces a dynamic multiperiod restriction: the manipulation of earnings reverses over time by the natural operation of the accounting system, which also mitigates the tendency to manipulate reported earnings. The upshot of these studies is that the expected level of earnings management is greater than zero.

\subsection{Agency Explanations for Managing Earnings and Dividends}

Guay, Kothari and Watts (1996) identify a variety of motivations for managing or smoothing earnings. Their "opportunistic accrual management hypothesis" proposes that earnings management can be a symptom of agency problems in the firm. Under this view, managers' private information regarding the true level of the firm's earnings is not revealed to shareholders. Misalignment of managers' and shareholders' incentives can result in managers using the flexibility provided by GAAP to manage income opportunistically, thereby creating 
distortions in reported profits (Watts and Zimmerman, 1986; Healy and Palepu, 1993.) This perspective is more closely related to the idea that earnings management occurs to misrepresent firm profitability and performance.

Researchers have proposed that dividend policy is also related to agency issues in a variety of ways. Easterbrook (1984) argues that regular dividend payments help investors monitor managerial behavior, as companies paying cash dividends must access capital markets more frequently to fund new investments than firms without regular payouts. Jensen (1986) builds on Easterbrook's arguments by asserting dividends increase the value of mature firms that generate large cash flows because they limit managers' tendency to waste excess capital on lowreturn investments. Siegel (2002) expands this line of thought by suggesting that historically high payouts helped limit accounting fraud as investors demanded "concrete evidence of real earnings" [p. A20] via regular dividend payments. He, et al. (2017) propose that dividend-paying firms engage in less accrual earnings management to mitigate agency concerns. The idea that dividends can mitigate potential agency concerns regarding misrepresented earnings (as identified by Guay, et al. 1996) complements the Skinner and Soltes (2011) view that dividendpaying firms have higher quality, more informative earnings.

\subsection{Smoother Streams of Earnings and Dividends are More Informative}

Guay, et. al (1996) also identify information-based motivations for managing or smoothing earnings. The market (or performance-measure) hypothesis asserts that a privatelyinformed manager seeks to influence investor perceptions of firm value. Under this hypothesis, a naturally-occurring conflict of interest between current shareholders and potential investors leads to a nonzero level of earnings management. The market hypothesis is consistent with the view that discretionary earnings smoothing enhances the informativeness and quality of earnings by communicating private information about firm profitability (Watts and Zimmerman, 1986; 
Holthausen, 1990; Healy and Palepu, 1993; Subramanyam, 1996; Hunt, Moyer and Shevlin, 2000).

Dividend policy is also thought to reveal information to investors. Linter's (1956) seminal model describes how managers partially smooth the permanent portion of recent earnings increases into the level of the firm's dividend. Subsequent research has proposed that dividend policy reflects information about the trend and sustainability of firms' past and current profits, ${ }^{4}$ and may also signal managers' expectations of future earnings. ${ }^{5}$ Dividends serve as credible signals because rival firms with less positive prospects find it difficult to imitate a sustained dividend payout. Whether dividends provide signals of future profits, or their information content is more corroborative, confirming that recent earnings changes are permanent (as in Lintner, 1956), the idea that dividend policy reveals information regarding firm profitability and value is consistent with the motivations for managing earnings described by Guay, et al. (1996).

\subsection{Firms Use Similar Methods to Smooth Earnings and Dividends}

Graham, et al. (2005) present survey evidence that reveals additional motivations for smoothing earnings and why these activities are so prevalent. CFOs believe that reporting smoother, less volatile earnings over time decreases the firm's cost of capital. Additionally, CFOs view earnings as the key metric considered by outsiders, and perceive a natural tradeoff between delivering expected earnings and investing in value-maximizing projects. While CFOs indicate they will sacrifice some economic value by adjusting the timing of real activities to meet earnings expectations, they are more reluctant to make small within-GAAP adjustments to

\footnotetext{
${ }^{4}$ Benartzi, Michaely and Thaler (1997), Dyl and Weigand (1998), Grullon, Michaely and Swaminathan (2002), Koch and Sun (2004), Grullon, Michaely, Benartzi and Thaler (2005), Fargher and Weigand (2009).

${ }^{5}$ Watts (1973), Bhattacharya, 1979, Gonedes (1978), Miller and Rock (1985), John and Williams (1985), Healy and Palepu (1988), Nissim and Ziv (2001).
} 
discretionary accrual accounts. ${ }^{6}$ It is well-known that firms also smooth dividends, and the earnings of dividend-paying firms are more persistent than those of non-payers. ${ }^{7}$ Skinner and Soltes (2011) conclude that the commitment to pay a dividend can help convince investors of the quality of reported earnings: "... dividends provide information about earnings quality, where high quality earnings are more likely to be sustainable in future periods" (p. 2).

Firms make comparable tradeoffs to achieve smooth earnings and dividends. Up to 80 percent of CFOs admit to laying off employees and decreasing spending on research and development, advertising and maintenance to meet an EPS benchmark, and 55 percent indicate that they have delayed investing in value-increasing projects (Graham, et al. 2005). Firms engage in similar activities to avoid reducing dividends, including selling assets, borrowing heavily and foregoing investment in positive NPV projects (Brav, et al. 2005). The earnings and dividend goals targeted by managers are also comparable. The imperative to report earnings and dividends per share that are at least equal to their levels from four quarters ago is particularly clear in CFOs' survey responses.

The fact that managers are willing to postpone or forego a considerable level of real activity to achieve smooth earnings and dividends suggests that the valuation benefits of smoothing are significant. Dividend-paying firms are thought to engage in additional earnings

\footnotetext{
${ }^{6}$ Graham, et al. (2005) note that their findings contrast with the well-established premise that firms manage both real activities and accruals to meet or beat earnings benchmarks (Guay, et al., 1996; Burgstahler and Dichev, 1997; Degeorge, Patel and Zeckhauser, 1999): "This evidence is somewhat disconcerting, considering the large volume of literature devoted to documenting earnings management via accruals and discretionary accruals" [p. 36]. The timing of the Graham, et al. (2005) survey, which was conducted immediately after passage of Sarbanes-Oxley, may partially explain why their findings differ from previous research. For example, Cohen, Dey and Lys (2008) report that real earnings management increased significantly following passage of Sarbanes-Oxley, with a proportional decline in accrual-based earnings management.

${ }^{7}$ Lintner (1956), Brav, et al. (2005), Leary and Michaely (2011), Skinner and Soltes (2011), Liu and Espahbodi (2014).
} 
smoothing because firm value is positively related to the quality (smoothness, persistence and predictability) of firms' earnings and dividend streams. ${ }^{8}$

\subsection{Standard Earnings Management Metrics, Firm Performance and Hypotheses}

The literature discussed in the previous four subsections suggests that earnings management is pervasive; that while there is non-zero level of earnings management, earnings management is naturally self-correcting in most cases; that earnings management may enhance the quality and informativeness of earnings or be opportunistic; that there are variety of motivations to manage earnings; that dividend policy reveals information regarding firm profitability and value; and that firms make comparable tradeoffs to achieve smooth earnings and dividends. In general, the literature views earnings management as a single-objective, singleperiod, opportunistic activity aimed at overstating income. This viewpoint as well as the use of standard measures of earnings management pose problems, and are partially recognized by prior research. For example, Ball and Shivakumar (2008) conclude that a bias exists toward identifying earnings management among IPO firms too frequently, and that this tendency also exists in "... a broad genre of studies on earnings management" [p. 346]. These authors show that some of this bias is due to methodologically inadequate controls for firm performance. We assert that dividend changes are a better measure of firm performance trajectory because dividends are not directly subject to earnings management, ${ }^{9}$ and changes in dividends reveal information about firm performance over multiple periods.

Previous research has also found that standard measures of earnings management may not be sufficient to identify earnings management practices that support multiple objectives, such

\footnotetext{
${ }^{8}$ Venkatesh (1989), Dyl and Weigand (1998), Brav, et al. (2005), Daniel, et al. (2008), Skinner and Soltes (2011), Leary and Michaely (2011).

${ }^{9}$ For example, Kim, Lee, and Lie (2017) present evidence that earnings management to avoid cutting dividends is not as prevalent as reported in previous studies.
} 
as meeting EPS and DPS targets while reporting smooth streams of earnings and dividends over time. Dichev, et al. (2013) support this view when they conclude that "CFOs believe that it is difficult for outside observers to unravel earnings management, especially when such earnings are managed using subtle unobservable choices or real actions" [p. 29]. In our view, if professional analysts find it difficult to draw such distinctions, models based mainly on deviations from subindustry averages may confound performance-driven practices with evidence of active earnings management, particularly when there are substantial differences in performance across companies.

We argue that much of what appears to be unusual or abnormal levels of discretionary accruals and real activities may actually be evidence of cross-sectional dispersion in the performance trajectory of firms within their subindustry classifications. Finding that high performance firms have lower abnormal accruals is consistent with the explanation that these firms require less working capital because they have more efficient operations. ${ }^{10}$ Firms with high performance trajectories also have economic incentives to accelerate spending on CAPEX and SG\&A due to their expectation that higher levels of long-term investment and spending will result in larger payoffs. Conversely, low performing firms hold more working capital (and thus have higher abnormal accruals) and have less economic incentive to increase spending on CAPEX and SG\&A. Similarly, finding that high performing firms have higher abnormal realactivities earnings management is consistent with the explanation that these firms are more efficient (i.e., they spend a smaller percentage of their sales on SG\&A relative to their subindustries), again in line with their superior performance trajectories.

\footnotetext{
${ }^{10}$ Ball and Shivakumar (2008) document a similar bias when firms hold unusually high levels of working capital: $" . .$. using IPO proceeds for investing in working capital items ... by definition causes positive accruals ... and creates the appearance of earnings management" (p. 326).
} 
The simultaneous targeting of specific EPS and DPS levels and similarity of the motivations guiding firms' earnings and dividend smoothing activities suggest three hypotheses. The first two hypotheses follow from our assertion that dividend increases are driven by stronger performance trajectory, and that for dividend-paying firms, conventional earnings management metrics reflect firm performance trajectory:

H1. Standard measures of earnings management will be more closely related to multiperiod firm performance (measured as the percentage change in a firm's annual dividend) than with unexpected earnings.

H2. Lower levels of discretionary accruals and higher levels of discretionary real activities (usually interpreted as signs of excessive earnings management) will be associated with a higher probability of increases in dividends (reflecting stronger multiperiod performance).

Finding that earnings management metrics are related to dividend changes rather than earnings surprises and that firms engaging in an apparently greater degree of earnings management are more likely to increase their dividends supports our hypothesis that conventional earnings management metrics are influenced by firm performance trajectory.

Our third hypothesis follows from signaling theory predictions that dividend changes provide investors with information regarding firm value, and tests our proposition that firms' performance goals take precedence over their earnings management activities:

H3. Stock returns around dividend announcement dates will have a stronger relation with the dividend change performance signal than standard measures of earnings management. Finding that dividend changes convey more value-relevant information to investors than firms' apparent earnings management activities further supports our view that conventional earnings 
management metrics reflect firm performance trajectory, and this information is more directly conveyed to investors via the dividend change announcement.

\section{Variables, Sample and Methodology}

Appendix A describes the variables used in this study. The variables include financial statement items, managerial compensation and institutional ownership data, dividends, stock returns, and analysts' forecasts of EPS. The sample consists of all publicly-traded firms in Compustat's ExecuComp database from 1994-2013 for which the following data are available: institutional ownership in the Wharton Research Data Services GMI database, dividends and stock returns in the Center for Research in Security Prices (CRSP) database, and analyst earnings forecasts in the I/B/E/S database. Consistent with prior literature, we omit firms in regulated industries and financial institutions (Roychowdhury 2006; Daniel et al. 2008; Skinner and Soltes, 2011; Liu and Espahbodi, 2014; Cheng, Lee and Shevlin, 2016). To derive reliable estimates of the various earnings management metrics we also delete firm-years with less than eight observations in each two-digit SIC industry in each year (Cohen, Dey and Lys, 2008; Cohen and Zarowin, 2010; Liu and Espahbodi, 2014; Cheng, et al. 2016). Additionally, we control for outliers by deleting firm-years with compensation and institutional ownership at the extreme $99^{\text {th }}$ percentile levels and all other variables at the $1^{\text {st }}$ and $99^{\text {th }}$ percentiles of their respective distributions (Burgstahler and Dichev, 1997; Dechow, Kothari and Watts, 1998; Dechow, Richardson and Tuna, 2003).

Our hypotheses require that we examine firm's earnings management activities around dividend change events. We therefore further restrict the sample to firms that have paid regular dividends on common stock in the current and prior year. These restrictions result in a sample of 4,277 firm-years over the period 1994-2013, among which are 1,696 firm-years in which the 
change in dividends equals zero. Thus, the final sample for testing our hypotheses includes 2,581 firm-years (2,482 dividend increases and 99 dividend decreases).

We use three earnings management metrics: abnormal accruals, abnormal discretionary expenditures, and abnormal production costs. ${ }^{11}$ Normal total accruals are estimated using the cross-sectional model of Jones (1991), controlling for financial performance as in Kothari, et al. (2005). Normal discretionary expenditures and normal production costs are estimated using models developed by Dechow, et al. (1998). These models are commonly used in the earnings management literature (e.g., see Roychowdhury 2006; Cohen et al. 2008; Cohen and Zarowin, 2010; Liu and Espahbodi 2014; Cheng, et al. 2016). Specifically, we estimate the following regression models, shown as Equations 1-3, in which $T A$ equals total accruals, defined as income before extraordinary items (IBEI) less cash flow from operations $(C F O)$; $P P E$ is property, plant, and equipment; $S G A$ is selling, general and administrative expenses; and $P R O D$ is production costs, defined as the sum of cost of goods sold and change in inventory. Each regression is estimated separately for each two-digit SIC industry for every year:

$$
\begin{aligned}
& \text { TA }_{t} / \text { Assets }_{t-1}=\alpha_{0}\left(1 / \text { Assets }_{t-1}\right)+\alpha_{1}\left(\Delta \text { Sales }_{t} / \text { Assets }_{t-1}\right)+ \\
& \alpha_{2}\left(\text { PPE }_{t} / \text { Assets }_{t-1}\right)+\alpha_{3}\left(\text { IBEI }_{t} / \text { Assets }_{t-1}\right)+\varepsilon_{t} \\
& \text { SGA }_{t} / \text { Assets }_{t-1}=\alpha_{0}\left(1 / \text { Assets }_{t-1}\right)+\alpha_{1}\left(\text { Sales }_{t-1} / \text { Assets }_{t-1}\right)+\varepsilon_{t} \\
& \text { PROD }_{t} / \text { Assets }_{t-1}=\alpha_{0}\left(1 / \text { Assets }_{t-1}\right)+\alpha_{1}\left(\text { Sales }_{t} / \text { Assets }_{t-1}\right)+ \\
& \alpha_{2}\left(\Delta \text { Sales }_{t} / \text { Assets }_{t-1}\right)+\alpha_{3}\left(\Delta \text { Sales }_{t-1} / \text { Assets }_{t-1}\right)+\varepsilon_{t}
\end{aligned}
$$

Abnormal total accruals $(R A C C R)$, abnormal discretionary expenditures and abnormal production costs $(R P R O D)$ are computed as the difference between their actual values and the

\footnotetext{
${ }^{11}$ We do not include abnormal cash flows since the net effect of earnings management activities on cash flows is ambiguous (Roychowdhury, 2006).
} 
normal levels predicted; i.e., they are the residuals from models 1-3, respectively. Abnormal discretionary expenditures are multiplied by -1 (and denoted as $R S G$ ) so that a higher value in all cases indicates greater upward earnings management. We define real earnings management (REM) as the sum of $R S G$ and RPROD. Note that Equation (1), which estimates normal total accruals, controls for firm past performance by including a term for return on assets as recommended by prior research (e.g., Kothari, et al., 2005; Hribar and Nichols, 2007) and implemented in many studies (e.g., Daniel, et al., 2008; Liu and Espahbodi, 2014). ${ }^{12}$

We estimate model (4) below to test our first hypothesis regarding the relation between earnings management and firm performance trajectory. Specifically, we investigate whether measures of real and accruals-based earnings management are more closely related to multiperiod firm performance than earnings surprises, using the percentage change in dividends ( $\%$ ch. Div) as the multiperiod performance signal:

$$
\begin{aligned}
& \text { Earnings Mngt. Proxy }=\beta_{0}+\beta_{1} \% \text { ch. Div }+\beta_{2} \text { Earnings Surprise }+ \\
& \beta_{3} \text { Change in CFO }+\beta_{4} \text { Change in Capital Spending }+\beta_{5} \text { SIZE }+\beta_{6} L E V+ \\
& \beta_{7} \text { COMP }+\beta_{8} \text { INSTOWN }+\beta_{9} M / B+\beta_{10} L N(\text { age })+\varepsilon
\end{aligned}
$$

The earnings management metrics defined above as $R A C C R, R S G, R P R O D$ and $R E M$ are the dependent variables in the regression models. Earnings Surprise equals actual annual EPS as reported by $\mathrm{I} / \mathrm{B} / \mathrm{E} / \mathrm{S}$ minus the median of the most recent analysts' consensus forecast before the earnings release date divided by the absolute value of actual EPS. If the absolute value of EPS for a firm is less than the 10-percentile value for the year for all firms in the sample, the 10-

\footnotetext{
${ }^{12}$ To test the sensitivity of our results, we add the return on assets to Equation (2) and Equation (3) as well. The results still indicate that dividend increasers manage earnings through real activities to a greater extent than dividend decreasers. We conjecture that two factors lead to this result: (1) return on assets is a measure of performance in a single period, and as such does not necessarily reflect performance trajectory; and (2) return on assets is based on reported earnings, which are affected by earnings management practices.
} 
percentile value is used as the scalar. ${ }^{13}$ Change in $C F O$ (cash flow from operations) and change in capital spending are percentage changes over the previous 12 months. Size is the natural logarithm of the market value of common equity at the beginning of the period. Lev is leverage, and is equal to total debt divided by total assets, both at the beginning of the period. COMP equals total current compensation other than salary as a percentage of total current compensation. COMP is included to control for compensation incentives (Bergstresser and Philippon, 2006; Cohen et al. 2008; Jiang, Petroni and Wang, 2010). We include institutional ownership $(I N S T O W N)$ because institutions serve a monitoring function in corporate governance that can affect the degree of earnings management (Chen, Cheng, Lo and Wang 2015; Cheng, et al. 2016). We include Change in CFO, Change in capital spending, firm size (SIZE), leverage $(L E V)$, growth opportunities $(M / B)$, and firm age $(L N($ age $))$ in the model because prior research has established that financial characteristics and the life-cycle stage of firms affect their dividend policy (e.g., Healy and Palepu, 1988; Grullon, et al. 2002; Skinner and Soltes, 2011).

Our second hypothesis proposes that firms that appear to engage in more earnings management are stronger performers, and thus are more likely to increase their dividends. We test this hypothesis using the logistic regression model shown as Equation (5), which estimates the probability that a firm will increase its dividend as a function of earnings management metrics and earnings surprise, controlling for factors that influence management's incentives to manage earnings and for differences in the financial characteristics and life-cycle stage of dividend-paying firms. $P A Y C H$ is the dividend increaser dummy variable, which equals 1 if a firm increases its dividend in the current year, and 0 otherwise. Earnings Mngt. is the earnings

\footnotetext{
${ }^{13}$ A small value for the absolute value of actual earnings per share renders very large values for Earnings surprise. We thus change the scalar for small absolute values of actual earnings per share to a common value to avoid distorting measures of Earnings Surprise.
} 
management metric: $R A C C R, R S G, R P R O D$ and $R E M$. All other variables are as previously defined:

$$
\begin{aligned}
\operatorname{Prob}(P A Y C H=1)= & \beta_{0}+\beta_{1} \text { Earnings Mngt. }+\beta_{2} \text { Earnings Surprise }+ \\
& \beta_{3} \text { Change in } C F O+\beta_{4} \text { Change in Capital Spending }+ \\
& \beta_{5} \text { SIZE }+\beta_{6} L E V+\beta_{7} C O M P+\beta_{8} \text { INSTOWN }+ \\
& \beta_{9} M / B+\beta_{10} L N(\text { age })+\varepsilon
\end{aligned}
$$

Our last hypothesis examines whether dividend change announcements convey more value-relevant information to investors than firms' apparent earnings management activities. We test this hypothesis using regression model depicted in Equation (6):

$C A R_{3}=\beta_{0}+\beta_{1} \%$ ch. Div $+\beta_{2}$ Earnings Mngt. $+\beta_{3}$ Change in CFO + $\beta_{4}$ Change in Capital Spending $+\beta_{5}$ SIZE $+\beta_{6} L E V+\beta_{7} C O M P+$ $\beta_{8}$ INSTOWN $+\beta_{9} M / B+\beta_{10} L N($ age $)+\varepsilon$

$C A R_{3}$ is the three-day cumulative abnormal return around the dividend declaration date (from days -1 to +1 ) for each dividend change event. All other variables are as previously defined. A significant and positive coefficient on \% ch. Div and an insignificant coefficient on Earnings Mngt. provides support for the idea that dividend change announcements convey more value-relevant information to investors than the apparent earnings management activities associated with firms' efforts to manage earnings and dividends and achieve their EPS and DPS targets.

\section{Empirical Results}

Descriptive statistics are shown in Table 1. Descriptors are presented for the full sample (Panel A), firms decreasing dividends (Panel B), and firms increasing dividends by percentage amounts that are smaller or larger than their subindustry medians (Panels C and D, respectively). 
The percentage changes in dividends are substantially different for the three subsamples. The mean (median) dividend change equals $-18.0 \%(-16.9 \%)$ for dividend decreasers, $+2.0 \%$ $(+1.8 \%)$ for small increasers, and $+5.4 \%(+4.2 \%)$ for large increasers. The mean three-day cumulative abnormal return around the announcement of dividend change $\left(\mathrm{CAR}_{3}\right)$ is negative for decreasers $(-1.4 \%)$ and positive for small increasers $(0.4 \%)$ and large increasers $(0.6 \%)$. Median values exhibit similar patterns. These results are consistent with the idea that firm value is positively related to changes in dividends.

[Insert Table 1]

Average abnormal accruals $(R A C C R)$ equal -0.029 for decreasers, and -0.042 and -0.043 for small and large increasers. The earnings-management-based explanation for this finding is that dividend increasers engage in more downward management of income. The performance-based interpretation of the difference in abnormal accruals is that dividend increasers are stronger performers and hold lower amounts of working capital, resulting in lower actual accruals. Therefore, their abnormal accruals, i.e., actual - expected, will be more negative. The multiperiod evidence reported in Table 3 and discussed below is consistent with the latter interpretation.

Mean abnormal SG\&A expense $(R S G)$ equals 0.005 for decreasers, and 0.042 and 0.036 for small and large increasers, which suggests more apparent upward management of income by firms increasing dividends through decreasing SG\&A expense. The performance-based interpretation of the difference in $R S G$ is that firms increasing dividends are stronger performers (i.e., they are more efficient), yielding a higher profit margin or turnover (sales/assets) on their investments in R\&D, advertising and capital expenditures. The same conclusion can be reached from the results on production and total real-activities-based earnings management (RPROD and 
$R E M$ - the sum of $R S G$ and $R P R O D)$. Mean RPROD equals - 0.081 for decreasers, but only 0.051 and -0.057 for small and large increasers; REM equals -0.076 for dividend decreasers, but only -0.008 and -0.020 for small and large increasers. This suggests lower downward earnings management through production and total real activities by high-performing firms. The performance-based explanation is that dividend increasers enjoy higher efficiency in production perhaps due to accelerated expenditures on R\&D and capital expenditures (the mean year-overyear percentage change in capital expenditures for dividend decreasers is $-2.1 \%$, and that for small and large dividend increasers are $+11.7 \%$ and $+16.5 \%$ ).

Table 1 also shows that the mean and median $\mathrm{M} / \mathrm{B}$ ratios increase monotonically across the three subsamples, which is consistent with the idea that investors perceive better performance trajectory for firms that increase dividends by greater amounts compared with firms that decrease dividends. Dividend-increasing firms also use a greater percentage of incentive-based compensation, which would be a rational decision for both the boards and managers of higherperforming firms.

We next establish that dividend change events reveal information regarding multiperiod firm performance. Panels A-F of Table 2 report the cumulative compound percentage change in total revenue, income before extraordinary items, dividends per share, cash flow from operations capital expenditures, and SG\&A expense from years -3 to +3 relative to each dividend change announcement. We find that firms announcing the most positive (negative) percentage change in dividends at time zero are on the highest (lowest) performance trajectories, as evidenced by faster (slower) growth in revenues, profits, dividends, cash flows, capital expenditures and SG\&A. These findings are consistent with the idea that dividend change events reveal information regarding multiperiod firm performance across a variety of dimensions. 
[Insert Table 2]

We extend our univariate analysis by examining real and accruals-based earnings management metrics spanning years -3 to +3 relative to the dividend change announcement. Panels A-D of Table 3 report the year-by-year median RACCR, RSG, RPROD and REM for the three groups of dividend-payers. Panel A ( $R A C C R)$ shows that firms that increase dividends in year zero appear to engage in more downward earnings management than dividend decreasers in every year. This finding is not consistent with the multiperiod reversal in accrual-based earnings management activities predicted by previous research, nor is it consistent with the "big bath" or "cookie jar" explanation. It is, however, consistent with the view that dividend increasing firms are on stronger performance trajectories (as shown in Table 2). Holding lower working capital allows these firms to direct a greater percentage of the firm's resources into capital assets, based on the expectation that higher levels of investment will yield higher payoffs.

[Insert Table 3]

Panel B of Table 3 reports year-by-year median abnormal SG\&A expense $(R S G)$ for the three groups of dividend payers. Firms increasing dividends appear to engage in more upward management of earnings through SG\&A expense over years -3 to +3 compared with firms that decrease dividends. A straightforward explanation for this finding is that high-performing firms (increasers) have more efficient operations than their subindustry peer groups.

Panel C of Table 3 reports year-by-year median abnormal production cost (RPROD), which is the second component of real activities-based earnings management. Although there is virtually no difference in the median $R P R O D$ of the three groups, it is noteworthy that no multiperiod reversal or big bath/cookie jar effects are present. 
Panel D of Table 3 reports total real earnings management $(R E M)$, which is the sum of $R S G$ and $R P R O D$. As there was virtually no difference in the $R P R O D$ of the three groups, the differences in $R E M$ are largely driven by the differences in $R S G$ reported in Panel $\mathrm{B}$. We see that the $R E M$ of dividend increasers is consistently greater than that of the dividend-decreasing subsample in years -3 to +3 , consistent with the idea that high-performance firms with superior prospects spend more on capital assets.

\subsection{Multivariate Analysis of Earnings Management Metrics and Firm Performance}

The evidence presented in Tables 1-3 provides some support for the ideas that dividend changes reveal information regarding multiperiod firm performance, and that conventional earnings management metrics are influenced by differences in the performance trajectory of firms within their subindustry classifications. We next test our first formal hypothesis using the regression model shown as Equation (4), namely that standard measures of earnings management will have a stronger statistical relation with multiperiod firm performance (measured as the percentage change in a firm's annual dividend) than with unexpected earnings, which are the supposed targets of firms' smoothing activities. Results are shown in Table 4, using the earnings management metrics RACCR, RSG, RPROD and REM as the dependent variables in Models 1-4, respectively. The key variables of interest are \% ch. Div and Earnings Surprise.

[Insert Table 4]

In Model 1, which uses $R A C C R$ (abnormal total accruals) as the dependent variable, the regression coefficients on both the \% ch. Div and Earnings Surprise variables are statistically insignificant at conventional levels. These results are consistent with $\mathrm{He}$, et al. (2017), who find that dividend-paying firms are less likely to engage in accruals-based earnings management than non-payers. Models 2-4 use the real activities-based earnings management metrics $R S G, R P R O D$ 
and $R E M$, respectively, as the dependent variables. In each of these models, the coefficient on $\%$ ch. Div is positive and statistically significant at either the $1 \%$ or $5 \%$ level, and the Earnings Surprise variable is insignificant. These findings support our first hypothesis, namely that conventional earnings management metrics reveal information about multiperiod firm performance — at least for real activities-based measures — rather than the unexpected earnings at which firms' smoothing activities are targeted.

The positive relation between the real activities-based earnings management metrics and dividend changes does not indicate that firms are engaging in more upwards earnings management in order to increase dividends. Recall that firms reporting the largest increases in dividends are also better performers (Table 2). If earnings were being managed upward to justify larger dividend increases, we would expect firms to reduce, rather than accelerate, capital and SG\&A expenditures.

We next present a test of our second hypothesis, which proposes that firms that appear to engage in earnings management to a greater degree are actually stronger performers, and thus are more likely to increase their dividends. We test this hypothesis using logistic regression (Equation 5) to model the probability that a firm will increase its dividend as a function of various earnings management metrics and earnings surprise, controlling for the same factors as in the earnings management regressions described above. The results are reported in Table 5. The coefficients on all the real earnings management metrics (Models 2-4) are positive and significantly different from zero at the $1 \%$ level, while those for Earnings Surprise are not significantly different from zero. This indicates that firms that appear to engage in more earnings management via real activities — or firms on high-performance trajectories — are more likely to increase their dividends. The \% ch. Capital Spending variable is also significant in Models 1-4, 
which supports the latter idea that firms that increase their dividends are actually stronger performers and not earnings manipulators. Abnormal total accruals $(R A C C R)$ is not significantly related to the odds of increase in dividends.

[Insert Table 5]

Each estimated coefficient in a logistic regression model in Table 5 measures the effect of a one-unit change in the corresponding variable on the logarithm of the odds ratios $\left(\ln \left(\frac{p}{1-p}\right)\right)$ that a firm will increase its dividend, holding all other variables in that model constant. Table 6 presents the change in the odds ratios $\left(\frac{p}{1-p}\right)$ and in probabilities $(p)$ as a result of a one-unit change in the corresponding variable.

[Insert Table 6]

In Model 1, the odds ratio (probability) for $R A C C R$ equals 0.1239 (.110), indicating that a one-unit increase in RACCR increases the odds (probability) of a dividend increase by 0.12 (11\%). This finding is consistent with the idea that accrual-based earnings management is not significantly related to dividends change decisions. By contrast, a one unit change in RSG, RPROD, or REM increases the odds (probability) of an increase in dividends by much greater amounts, ranging from 2.92 to 7.37 (74.5\% to $88.1 \%)$. This finding supports the idea that highperformance firms that invest and spend more are also more likely to increase dividends.

Our third hypothesis states that stock returns around dividend announcement dates will have a stronger relation with the dividend change performance signal (i.e., performance trajectory) than standard measures of earnings management associated with firms' efforts to smooth earnings and dividends and achieve their EPS and DPS targets. We test this hypothesis 
by regressing the three-day cumulative abnormal return around the dividend change announcement date on each earnings management measure, the percentage change in dividends per share, and the control variables described above. The results are reported in Table 7. We find a positive and significant relation between the announcement period return and the percentage change in dividends in each model. The coefficients of abnormal accruals (Model 1) and all the real earnings management metrics (Models 2-4) are insignificant. The results confirm the wellestablished view that changes in dividends convey information to investors. They further indicate that the activities used to smooth earnings and dividends, typically classified as earnings management, convey less value-relevant information to investors compared with the degree to which dividend-paying firms are able (or find it necessary) to change their dividend level. These results suggest investors focus more on firms' multiperiod performance trajectories than the smoothing activities that contributed to the firm's ability (or necessity) to change the dividend.

\section{[Insert Table 7]}

\section{Summary and Conclusions}

We argue that the frequency with which firms engage in opportunistic earnings management is overstated in the academic literature due to a variety of factors. Among these are the competing imperatives to report smooth streams of high quality earnings over time while adhering to the principle of faithful representation; the tendency to measure earnings management as a single-period activity; and the failure of standard earnings management metrics to fully account for multiperiod firm performance.

We propose that "abnormal" levels of discretionary accruals and real activities reflect more information about cross-sectional differences in the performance trajectories of firms within their subindustry classifications than about active attempts to manage earnings. We test 
our proposition using dividend change as a natural setting that involves a multiobjective and multiperiod decision and that distinguishes high from low performance trajectory firms. Survey evidence suggests that earnings and dividends are managed (or smoothed) jointly, mainly by adjustments to real activities across fiscal periods (Graham, et. al, 2005 and Brav, et. al, 2005). This implies both multiobjective and multiperiod effects and a relation with firm performance.

We first establish that dividend changes indeed reflect information regarding firms' multiperiod performance by sorting our sample of firms into three groups based on the percentage change in dividends (large increasers, small increasers and decreasers) and examining changes/growth in revenues, profits, dividends, cash flows, and capital and SG\&A expenditures, over years -3 to +3 relative to the dividend change announcement. We find that firms announcing the most positive (negative) percentage change in dividends at time zero are on the highest (lowest) performance trajectory (spanning), as evidenced by faster (slower) growth in revenues, profits, dividends, cash flows, and capital and SG\&A expenditures. These findings provide comfort in using the percentage change in dividends announced at time zero as a signal of firm performance trajectory throughout our study.

We then calculate the standard accruals and real-activities earnings management metrics for the three groups of firms and find that small and large increasers exhibit lower abnormal accruals and higher abnormal SG\&A and total real earnings management. We attribute the results to differences in firms' performance trajectories. In particular, because dividend increasers are stronger performers (i.e., because they are more efficient), they hold lower amounts of working capital, resulting in lower actual accruals and thus lower abnormal accruals. These firms also yield a higher profit margin or turnover (sales/assets) on their investments, resulting in lower actual SG\&A and thus higher abnormal SG\&A and total real earnings 
management. Our findings are not consistent with the explanation that firms engage in more upwards earnings management to justify larger dividend increases or to avoid dividend cut. Firms that raise dividends by the greatest amount also have the highest growth in capital expenditures and SG\&A. If earnings were being managed higher to justify larger dividend increases, we would expect firms to delay, rather than accelerate, the pace at which they are spending on real activities.

We model various real and accruals-based earnings management metrics as a function of firms' most recent dividend change and earnings surprise, controlling for factors thought to affect firms' incentives to manage earnings and for differences in the life-cycle and financial characteristics of dividend-paying firms. We find that standard measures of earnings management based on real activities are positively related to the dividend change performance signal, but unrelated to the unexpected earnings at which firms' smoothing activities are supposedly targeted. These results support the idea that the earnings management metrics reveal more information about firm performance trajectory than about active attempts to manage earnings.

Next, we model the probability that a firm will increase its dividend as a function of earnings management metrics and earnings surprises, controlling for the same variables as in the above regressions. We find that firms that have higher growth in capital expenditures - which would be expected from firms on high-performance trajectories — are more likely to increase their dividends. The unexpected earnings at which firms' smoothing activities are supposedly targeted are not significantly related to the likelihood of a dividend increase. These results provide further support for the idea that standard earnings management metrics reflect more 
information about companies' performance trajectory and their ability to increase (or need to decrease) dividends.

Finally, we test whether stock returns around dividend announcement dates have a stronger relation with the dividend change performance signal than standard measures of earnings management. We regress the three-day cumulative abnormal return around the dividend change announcement on various earnings management metrics, the percentage change in dividends per share, and various financial and firm life-cycle control variables. The announcement period return is positively related to the percentage change in dividends in each model; all earnings management metrics are insignificant. These results suggest investors focus more on firms' multiperiod performance than the smoothing activities that contributed to the firm's ability (or requirement) to change the dividend.

Our findings provide a useful guide for possible reinterpretation of the results of numerous earnings management studies. For example, Kothari, Mizik and Roychowdhury (2016) find that firms that engage in the most downward manipulation of R\&D and SG\&A to overstate earnings at the time of seasoned equity offerings (SEOs) have the largest negative return reversals in subsequent years. Of course, firms that raise capital via SEOs are thought to be poorer long-term performers overall (Jegadeesh, 2000). An alternative interpretation of Kothari, et al.'s (2016) findings is that firms with less promising prospects are more likely to reduce spending on R\&D and SG\&A by greater amounts due to performance-related factors. Consistent with their poorer prospects, the long-term returns of these firms are also lower than firms that do not need to reduce spending on R\&D and SG\&A as drastically. Future research is likely to continue investigating the relation between firm performance and standard earnings management metrics, and in particular, whether our findings generalize to all firms, including those that do not 
pay dividends. Clearly, a measure of performance trajectory other than dividend change needs to be developed for non-dividend paying firms. 


\section{References}

Ali, A. and W. Zhang, 2015. CEO tenure and earnings management. Journal of Accounting and Economics 59, 60-79.

Ball, R. and L. Shivakumar, 2008. Earnings quality at initial public offerings. Journal of Accounting and Economics 45, 324-349.

Bhattacharya, S., 1979. Imperfect information, dividend policy, and "the bird in the hand fallacy." Bell Journal of Economics 10, 259-270.

Brav, A., J. Graham, C. Harvey, and R. Michaely, 2005. Payout policy in the 21st century. Journal of Financial Economics 77, 483-527.

Bergstresser, D. and T. Philippon, 2006. CEO incentives and earnings management. Journal of Financial Economics 80, 511-529.

Burgstahler, D. and I. Dichev, 1997. Earnings management to avoid earnings decreases and losses. Journal of Accounting and Economics 24, 99-126.

Chen, X., Q. Cheng, A. Lo, and X. Wang, 2015. CEO contractual protection and managerial shorttermism. The Accounting Review 90, 1871-1906.

Chen, S., T. Shevlin and Y. Tong, 2008. Does the pricing of financial reporting quality change around dividend changes? Journal of Accounting Research 45, 1-40.

Cheng, Q., J. Lee and T. Shevlin, 2016. Internal governance and real earnings management. The Accounting Review 91, 1051-1085.

Christensen, T. E., A. A. Huffman, and M. F. Lewis-Western, 2017. Earnings management proxies: Prudent business decisions or earnings manipulation? Available at SSRN: https://ssrn.com/abstract=2793838 or http://dx.doi.org/10.2139/ssrn.2793838.

Cohen, D., A. Dey and T. Lys, 2008. Real and accrual-based earnings management in the pre- and post-Sarbanes-Oxley periods, The Accounting Review 83, 757-787.

Cohen, D., S. Pandit, C. Wasley and T. Zach, 2016. Measuring real activity management. Available at SSRN: https://ssrn.com/abstract=1792639 and http://dx.doi.org/10.2139/ssrn.1792639.

Cohen, D. and P. Zarowin, 2010. Accrual based and real earnings management activities around seasoned equity offerings, Journal of Accounting and Economics 50, 2-19.

Collins, D., R. Pungaliya, and A. Vijh, 2016. The effects of firm growth and model specification choices on tests of earnings management in quarterly settings. The Accounting Review 92, 69-100.

Crocker, K. and Slemrod, J., 2007. The economics of earnings manipulation and managerial compensation. RAND Journal of Economics 38, 698-713.

Daniel, N., D. Denis and L. Naveen, 2008. Do firms manage earnings to meet dividend thresholds? Journal of Accounting and Economics 45, 2-26.

Dechow, P., R. Sloan and A. Sweeney, 1995. Detecting earnings management. The Accounting Review $70,193-225$.

Dechow, P., S. Richardson and I. Tuna, 2003. Why are earnings kinky? An examination of the earnings management explanation. Review of Accounting Studies 8, 355-384.

Dechow, P., G. Weili and C. Schrand, 2010. Understanding earnings quality: A review of the proxies, their determinants and their consequences. Journal of Accounting and Economics 50, 344-401. 
Dechow, P., S. Kothari and R. Watts, 1998. The relation between earnings and cash flows. Journal of Accounting and Economics 25, 133-168.

DeGeorge, F., J. Patel and R. Zeckhauser, 1999. Earnings management to exceed thresholds. Journal of Business 72, 1-33.

DeMarzo, P. and M. Fishman, 2007. Optimal long-term financial contracting. The Review of Financial Studies 20, 2079-2128.

Dichev, I., J. Graham, C. Harvey, and S. Rajgopal, 2013. Earnings quality: Evidence from the field. Journal of Accounting and Economics 56, 1-33.

Dutta, S., \& Q. Fan, 2014. Equilibrium earnings management and managerial compensation in a multiperiod agency setting. Review of Accounting Studies 19, 1047-1077.

Dye, R. A.,1988. Earnings management in an overlapping generations model. Journal of Accounting Research 26, 195-235.

Dyl, E. and R. Weigand, 1998. The information content of dividend initiations: Additional evidence. Financial Management 27, 27-35.

Easterbrook, F., 1984. Two agency-cost explanations of dividends. American Economic Review 74, 650-659.

Edmans, A., 2009. Blockholder trading, market efficiency, and managerial myopia. Journal of Finance 64, 2481-2513.

Fargher, N. and R. Weigand, 2009. Cross-sectional differences in the profits, returns and risk of firms initiating dividends. Managerial Finance 35, 509-530.

Fischer, P. E., \& R.E. Verrecchia, 2000. Reporting bias. The Accounting Review 75, 229-245.

Francis, J., R. LaFond, P. Olsson, and K. Schipper, 2004. Costs of equity and earnings attributes. The Accounting Review 79, 967-1010.

Francis, J., R. LaFond, P. Olsson, and K. Schipper, 2005. The market pricing of accruals quality. Journal of Accounting and Economics 39, 295-327.

Gonedes, N., 1978. Corporate signaling, external accounting, and capital market equilibrium: Evidence on dividends, income, and extraordinary items. Journal of Accounting Research 16, 2679.

Graham, J., C. Harvey and S. Rajgopal, 2005. The economic implications of corporate financial reporting. Journal of Accounting and Economics 40, 3-73.

Grullon, G., R. Michaely and B. Swaminathan, 2002. Are dividend changes a sign of firm maturity? Journal of Business 75, 387-424.

Grullon, G., R. Michaely, S. Benartzi and R. Thaler, 2005. Dividend changes do not signal changes in future profitability. Journal of Business 78, 1659-1682.

Guay, Wayne R., S. P. Kothari and R. Watts, 1996. A market-based evaluation of discretionary accruals models. Journal of Accounting Research 34, 83-105.

Gunny. K. A. (2010). "The relation between earnings management using real activities manipulation and future performance: Evidence from meeting earnings benchmarks". Contemporary Accounting Research. 27, 855-888.

Hansen, G. A., 1996. Do discretionary accrual proxies measure earnings management? Working paper, University of Rochester. 
He, W., L. Ng, and N. Zaiats, 2017. Dividend policy and earnings management across countries. Journal of Corporate Finance 42, 267-286.

Healy, P. M. and K. G. Palepu, 1988. Earnings information conveyed by dividend initiations and omissions. Journal of Financial Economics 21, 149-175.

Healy, P. M. and K. G. Palepu, 1993. The effect of firms' financial disclosure policies on stock prices. Accounting Horizons 7, 1-11.

Healy, P. M. and J. Wahlen, 1999. A review of the earnings management literature and its implications for standard setting. Accounting Horizons 13, 365-383.

Holthausen, R. W., 1990. Accounting method choice: opportunistic behavior, efficient contracting and information perspectives. Journal of Accounting and Economics 12, 207-218.

Hribar, P. and D. Nichols, 2007. The use of unsigned earnings quality measures in tests of earnings management. Journal of Accounting Research 45, 1017-1053.

Hunt, A., S. Moyer, and T. Shevlin, 2000. Earnings volatility, earnings management, and equity value. Working paper, University of Washington.

Jegadeesh, N., 2000. Long-term performance of seasoned equity offerings: Benchmark errors and biases in expectations. Financial Management 29, 5-30.

Jensen, M., 1986. Agency costs of free cash flow, corporate finance and takeovers. American Economic Review 76, 323-329.

Jiang, J., K. Petroni and I. Wang, 2010. CFOs and CEOs: Who have the most influence on earnings management? Journal of Financial Economics 96, 513-526.

John, K. and J. Williams, 1985. Dividends, dilution, and taxes: a signaling equilibrium. Journal of Finance 40, 1053-1070.

Jones, J., 1991. Earnings management during import relief investigations. Journal of Accounting Research 29, 193-228.

Kim, J., K. Lee, and E. Lie. 2017. Dividend stickiness, debt covenants, and earnings management. Contemporary Accounting Research 34, 2022-2050.

Koch, A. and A. Sun, 2004. Dividend changes and the persistence of past earnings changes. Journal of Finance 59, 2093-2116.

Kothari, S. P., A. Leone, and C. Wasley, 2005. Performance matched discretionary accrual measures. Journal of Accounting and Economics 39, 163-197.

Kothari, S. P., N. Mizik and S. Roychowdhury, 2016. Managing for the moment: The role of earnings management via real activities versus accruals in SEO valuation. The Accounting Review 91, 559586.

Kirschenheiter, M. and N. Melumad, 2002. Can "big bath" and earnings smoothing co-exist as equilibrium reporting strategies? Journal of Accounting Research 40, 761-796.

Leary, M. and R. Michaely, 2011. Determinants of dividend smoothing: Empirical evidence. Review of Financial Studies 24, 3197-3249.

Lintner, J., 1956. Distribution of incomes of corporations among dividends, retained earnings and taxes. American Economic Review 46, 97-113.

Liu, N. and R. Espahbodi, 2014. Does dividend policy drive earnings smoothing? Accounting Horizons 28, 501-528. 
Miller, M. and K. Rock, 1985. Dividend policy under asymmetric information. The Journal of Finance 40, 1021-1051.

Nissim, D. and A. Ziv, 2001. Dividend changes and future profitability. Journal of Finance 56, 2111 2133.

Perotti, P. and D. Windisch, 2017. Managerial discretion in accruals and informational efficiency. Journal of Business Finance \& Accounting 44, 375-416.

Roychowdhury, S., 2006. Earnings management through real activities manipulation. Journal of Accounting and Economics 42, 335-370.

Sankar, M.R. and K.R. Subramanyam, 2001. Reporting discretion and private information communication through earnings. Journal of Accounting Research 29, 365-386.

Siegel, J., 2002. Stocks for the Long Run, $3^{\text {rd }}$ ed., McGraw-Hill, New York, NY.

Skinner, D. J. and E. Soltes, 2011. What do dividends tell us about earnings quality? Review of Accounting Studies 16, 1-28.

Subramanyam, K. R., 1996. The pricing of discretionary accruals. Journal of Accounting and Economics 22, 249-281.

Venkatesh, P.C., 1989. The impact of dividend initiation on the information content of earnings announcements and returns volatility. Journal of Business 62, 175-197.

Watts, R. and J. Zimmerman, 1986. Positive Accounting Theory, Prentice-Hall, Englewood Cliffs, NJ. 


\section{Appendix A: Variable Definitions.}

\begin{tabular}{|c|c|}
\hline$\%$ ch. Div & Percentage change in ANNODIV,$=100 *\left(\right.$ ANNODIV $_{t}-$ ANNODIV $\left._{t-1}\right) /$ ANNODIV $_{t-1}$ \\
\hline ANNODIV & Annual ordinary dividends per share \\
\hline $\mathrm{CAR}_{3}$ & $\begin{array}{l}\text { Three-day cumulative abnormal returns around the dividend change declaration date (days } \\
\text {-1 to 1); individual firm returns are market adjusted by subtracting the return from the } \\
\text { CRSP value-weighted index on the same day }\end{array}$ \\
\hline $\mathrm{CFO}$ & Cash flow from operations \\
\hline $\begin{array}{l}\text { Change in } \\
\text { CAPEX }\end{array}$ & $\begin{array}{l}\text { The percentage change in capital expenditures over the } 12 \text { months preceding the dividend } \\
\text { announcement date }\end{array}$ \\
\hline Change in CFO & $\begin{array}{l}\text { The percentage change in operating cash flows over } 12 \text { months preceding the dividend } \\
\text { announcement date }\end{array}$ \\
\hline COMP & Incentive pay, $=$ total compensation less salary as a percentage of total compensation \\
\hline Earnings Surprise & $\begin{array}{l}\text { (Actual earnings per share as reported by } \mathrm{I} / \mathrm{B} / \mathrm{E} / \mathrm{S}-\text { median of the most recent analysts' } \\
\text { consensus forecast before the earnings release date) / absolute value of actual earnings per } \\
\text { share }\end{array}$ \\
\hline IBEI & Income before extraordinary items \\
\hline INSTOWN & $\begin{array}{l}\text { Institutional ownership, }=\text { total institutional ownership as a percentage of shares } \\
\text { outstanding }\end{array}$ \\
\hline LEV & Leverage, $=$ Total debt $_{t-1} /$ Assets ${ }_{t-1}$ \\
\hline LN (age) & $\begin{array}{l}\text { Firm age, = Natural logarithm of the age of the firm as of year } t \text {, where age is the } \\
\text { difference between year } t \text { and the first year in which the firm appears in the Compustat } \\
\text { database }\end{array}$ \\
\hline $\mathrm{M} / \mathrm{B}$ & Market value of common equity $t_{t-1} /$ book value of common equity $t_{t-1}$ \\
\hline $\mathrm{PAYCH}$ & Dividend increase indicator/dummy, $=1$ if $\% \mathrm{ch}$. Div is positive, and 0 otherwise \\
\hline PPE & Property, plant and equipment \\
\hline PROD & Production costs, $=$ cost of goods sold + change in inventory \\
\hline RACCR & $\begin{array}{l}\text { Abnormal total accruals, }=\text { Residual from the following regression for each two-digit SIC } \\
\text { industry per year: } \\
\text { TA }_{t} / \text { Assets }_{t-1}=\alpha_{0}\left(1 / \text { Assets }_{t-1}\right)+\alpha_{1}\left(\Delta \text { Sales }_{t} / \text { Assets }_{t-1}\right)+ \\
\alpha_{2}\left(P P E_{t} / \text { Assets }_{t-1}\right)+\alpha_{3}\left(\text { IBEI }_{t} / \text { Assets }_{t-1}\right)+\varepsilon_{t}\end{array}$ \\
\hline REM & Total real earnings management, $=\mathrm{RSG}+\mathrm{RPROD}$ \\
\hline
\end{tabular}




\begin{tabular}{|l|l|}
\hline \multirow{2}{*}{ RPROD } & $\begin{array}{l}\text { Abnormal production costs, }=\text { Residual from the following regression for each two-digit } \\
\text { SIC industry per year: }\end{array}$ \\
& $\begin{array}{l}\text { PROD }_{t} / \text { Assets }_{t-1}=\alpha_{0}\left(1 / \text { Assets }_{t-1}\right)+\alpha_{1}\left(\text { Sales }_{t} / \text { Assets }_{t-1}\right)+ \\
\alpha_{2}\left(\Delta \text { Sales }_{t} / \text { Assets }_{t-1}\right)+\alpha_{3}\left(\Delta \text { Sales }_{t-1} / \text { Assets }_{t-1}\right)+\varepsilon_{t}\end{array}$ \\
\hline RSG & $\begin{array}{l}\text { Abnormal discretionary expenditures, }=\text { Residual from the following regression for each } \\
\text { two-digit SIC industry per year multiplied by }-1: \\
S G A_{t} / \text { Assets }_{t-1}=\alpha_{0}\left(1 / \text { Assets }_{t-1}\right)+\alpha_{1}\left(\text { Sales }_{t-1} / \text { Assets }_{t-1}\right)+\varepsilon_{t}\end{array}$ \\
\hline SG\&A & Selling, general and administrative expenses \\
\hline SIZE & Firm size, $=$ Natural logarithm of market value of common equity $\mathrm{t}-1$ \\
\hline TA & Total accruals, $=$ IBEI - CFO
\end{tabular}


Table 1: Descriptive Statistics. This table reports descriptive statistics for a sample of firms that changed their dividend payment from 1994-2013. The sample includes all publicly-traded firms in Compustat's ExecuComp database that have paid dividends in the current and prior year, and for which the following data are available: institutional ownership in GMI database, dividends and stock returns in CRSP database, and analyst forecasts in $\mathrm{I} / \mathrm{B} / \mathrm{E} / \mathrm{S}$ database. Firms in regulated industries (utilities and financial institutions) are excluded, as are firm-years with less than eight observations in each two-digit SIC industry in each year. We control for outliers by deleting firm-years with compensation and institutional ownership at the extreme 99th percentile levels and all the other variables at the 1st and 99th percentiles of their respective distributions. Firms are sorted into 3 groups: dividend decreasers and firms that increase dividends by larger (smaller) amounts, measured as firms with percentage changes in dividends above (below) the industry median for all firms increasing dividends. Variables are defined in Appendix A.

\section{Panel A: Descriptive Statistics, Full Sample}

\begin{tabular}{rcrrrrr}
\hline Variable & N & Mean & 25th Pctl & Median & 75th Pctl & Std Dev \\
\hline CAR3 & 2581 & 0.003 & -0.016 & 0.002 & 0.020 & 0.036 \\
RACCR & 2581 & -0.037 & -0.068 & -0.032 & 0.002 & 0.060 \\
RSG & 2581 & 0.040 & -0.043 & 0.029 & 0.116 & 0.154 \\
RPROD & 2581 & -0.039 & -0.145 & -0.041 & 0.054 & 0.174 \\
REM & 2581 & 0.001 & -0.181 & -0.009 & 0.156 & 0.313 \\
\% ch. Div & 2581 & 1.877 & 0.000 & 1.174 & 3.226 & 5.239 \\
Earnings Surprise & 2581 & 0.001 & -0.005 & 0.007 & 0.026 & 0.146 \\
\% ch. Cash Flow & 2581 & 18.048 & -15.212 & 5.969 & 31.859 & 79.003 \\
\% ch. CAPEX & 2581 & 12.759 & -12.804 & 7.826 & 30.364 & 42.105 \\
SIZE & 2581 & 7.814 & 6.769 & 7.757 & 8.803 & 1.390 \\
LEV & 2581 & 0.215 & 0.122 & 0.215 & 0.306 & 0.132 \\
COMP & 2581 & 38.567 & 20.635 & 38.009 & 56.819 & 23.282 \\
INSTOWN & 2581 & 0.696 & 0.599 & 0.716 & 0.818 & 0.165 \\
M/B & 2581 & 3.147 & 1.754 & 2.470 & 3.594 & 2.770 \\
LN(age) & 2581 & 3.422 & 3.091 & 3.611 & 3.871 & 0.607 \\
\hline
\end{tabular}


Table 1 (continued).

Panel B: Descriptive Statistics, Firms Decreasing Dividends

\begin{tabular}{rcrrrrr}
\hline Variable & N & Mean & 25th Pctl & Median & 75th Pctl & Std Dev \\
\hline CAR3 & 99 & -0.014 & -0.039 & -0.007 & 0.011 & 0.045 \\
RACCR & 99 & -0.029 & -0.058 & -0.023 & 0.009 & 0.065 \\
RSG & 99 & 0.005 & -0.073 & 0.012 & 0.074 & 0.140 \\
RPROD & 99 & -0.081 & -0.162 & -0.061 & 0.020 & 0.166 \\
REM & 99 & -0.076 & -0.214 & -0.055 & 0.081 & 0.290 \\
\% ch. Div & 99 & -17.961 & -21.739 & -16.912 & -12.500 & 11.133 \\
Earnings Surprise & 99 & -0.002 & -0.033 & 0.003 & 0.037 & 0.157 \\
\% ch. Cash Flow & 99 & 17.857 & -30.624 & 5.242 & 28.330 & 121.531 \\
\% ch. CAPEX & 99 & -2.048 & -29.146 & -5.333 & 18.096 & 38.669 \\
SIZE & 99 & 7.508 & 6.621 & 7.366 & 8.401 & 1.340 \\
LEV & 99 & 0.242 & 0.128 & 0.261 & 0.361 & 0.150 \\
COMP & 99 & 33.177 & 7.667 & 30.594 & 52.288 & 25.984 \\
INSTOWN & 99 & 0.630 & 0.509 & 0.654 & 0.751 & 0.182 \\
M/B & 99 & 2.858 & 1.374 & 2.140 & 3.695 & 2.126 \\
LN(age) & 99 & 3.504 & 3.296 & 3.664 & 3.912 & 0.553 \\
\hline
\end{tabular}

Panel C: Descriptive Statistics, Firms Increasing Dividends by Smaller Percentage Amounts

\begin{tabular}{rcrrrrr}
\hline Variable & $\mathbf{N}$ & Mean & 25th Pctl & Median & 75th Pctl & Std Dev \\
\hline CAR3 & 1060 & 0.004 & -0.012 & 0.003 & 0.020 & 0.032 \\
RACCR & 1060 & -0.042 & -0.073 & -0.032 & -0.006 & 0.056 \\
RSG & 1060 & 0.042 & -0.051 & 0.026 & 0.123 & 0.158 \\
RPROD & 1060 & -0.051 & -0.158 & -0.062 & 0.046 & 0.172 \\
REM & 1060 & -0.008 & -0.200 & -0.028 & 0.161 & 0.316 \\
\% ch. Div & 1060 & 1.952 & 1.064 & 1.754 & 2.558 & 1.170 \\
Earnings Surprise & 1060 & 0.001 & -0.003 & 0.006 & 0.019 & 0.084 \\
\% ch. Cash Flow & 1060 & 15.739 & -11.850 & 6.120 & 28.258 & 61.896 \\
\% ch. CAPEX & 1060 & 11.741 & -9.562 & 8.226 & 27.876 & 34.202 \\
SIZE & 1060 & 8.167 & 7.220 & 8.024 & 9.028 & 1.288 \\
LEV & 1060 & 0.208 & 0.126 & 0.216 & 0.291 & 0.122 \\
COMP & 1060 & 41.118 & 23.550 & 41.075 & 59.498 & 22.814 \\
INSTOWN & 1060 & 0.685 & 0.604 & 0.695 & 0.784 & 0.150 \\
M/B & 1060 & 3.363 & 2.047 & 2.776 & 3.948 & 2.204 \\
LN(age) & 1060 & 3.595 & 3.466 & 3.784 & 3.912 & 0.502 \\
\hline
\end{tabular}


Table 1 (continued).

Panel D: Descriptive Statistics, Firms Increasing Dividends by Larger Percentage Amounts

\begin{tabular}{rcrrrrr}
\hline Variable & N & Mean & 25th Pctl & Median & 75th Pctl & Std Dev \\
\hline CAR3 & 1422 & 0.006 & -0.013 & 0.004 & 0.022 & 0.034 \\
RACCR & 1422 & -0.043 & -0.076 & -0.035 & -0.004 & 0.062 \\
RSG & 1422 & 0.036 & -0.051 & 0.020 & 0.110 & 0.156 \\
RPROD & 1422 & -0.057 & -0.166 & -0.068 & 0.034 & 0.178 \\
REM & 1422 & -0.020 & -0.209 & -0.047 & 0.133 & 0.317 \\
\% ch. Div & 1422 & 5.440 & 2.778 & 4.167 & 6.140 & 5.358 \\
Earnings Surprise & 1422 & 0.006 & -0.002 & 0.007 & 0.020 & 0.060 \\
\% ch. Cash Flow & 1422 & 17.555 & -9.058 & 8.237 & 30.182 & 70.532 \\
\% ch. CAPEX & 1422 & 16.532 & -7.919 & 11.881 & 33.371 & 41.007 \\
SIZE & 1422 & 8.078 & 7.042 & 8.072 & 9.099 & 1.375 \\
LEV & 1422 & 0.200 & 0.107 & 0.198 & 0.287 & 0.128 \\
COMP & 1422 & 40.274 & 23.194 & 39.798 & 58.381 & 23.119 \\
INSTOWN & 1422 & 0.692 & 0.587 & 0.713 & 0.816 & 0.164 \\
M/B & 1422 & 3.515 & 2.062 & 2.846 & 3.982 & 2.662 \\
LN(age) & 1422 & 3.380 & 2.996 & 3.555 & 3.850 & 0.603 \\
\hline
\end{tabular}


Table 2: Firm Performance Pre- and

Post-Dividend Change. This table reports the cumulative compound rate of change of six firm performance metrics from years -3 to +3 relative to the year in which each dividend change event is announced. Firms are partitioned into 3 groups: dividend decreasers, small increasers, and large increasers. Large (small) increasers are firms with percentage changes in dividends above (below) the industry median for all firms increasing dividends.

Panel A:

Change in Total Revenue

\begin{tabular}{cccc}
\hline Period & Decreasers & $\begin{array}{c}\text { Small } \\
\text { Increasers }\end{array}$ & $\begin{array}{c}\text { Large } \\
\text { Increasers }\end{array}$ \\
\hline-3 & $0.0 \%$ & $0.0 \%$ & $0.0 \%$ \\
-2 & $3.4 \%$ & $6.8 \%$ & $9.0 \%$ \\
-1 & $3.7 \%$ & $14.2 \%$ & $18.5 \%$ \\
0 & $3.2 \%$ & $22.0 \%$ & $27.9 \%$ \\
+1 & $7.4 \%$ & $29.8 \%$ & $36.9 \%$ \\
+2 & $14.3 \%$ & $37.7 \%$ & $45.7 \%$ \\
+3 & $19.9 \%$ & $45.5 \%$ & $55.0 \%$ \\
\hline
\end{tabular}

Panel B:

Change in Income Before Extraordinary Items

\begin{tabular}{cccc}
\hline Year & Decreasers & $\begin{array}{c}\text { Small } \\
\text { Increasers }\end{array}$ & $\begin{array}{c}\text { Large } \\
\text { Increasers }\end{array}$ \\
\hline-3 & $0.0 \%$ & $0.0 \%$ & $0.0 \%$ \\
-2 & $-8.4 \%$ & $10.9 \%$ & $16.9 \%$ \\
-1 & $-24.8 \%$ & $22.1 \%$ & $34.7 \%$ \\
0 & $-30.1 \%$ & $33.7 \%$ & $50.2 \%$ \\
+1 & $-16.7 \%$ & $45.9 \%$ & $62.4 \%$ \\
+2 & $-0.8 \%$ & $59.6 \%$ & $78.3 \%$ \\
+3 & $7.2 \%$ & $74.2 \%$ & $95.6 \%$ \\
\hline
\end{tabular}

Panel C:

Change in Dividends Per Share

\begin{tabular}{cccc}
\hline Year & Decreasers & $\begin{array}{c}\text { Small } \\
\text { Increasers }\end{array}$ & $\begin{array}{c}\text { Large } \\
\text { Increasers }\end{array}$ \\
\hline-3 & $0.0 \%$ & $0.0 \%$ & $0.0 \%$ \\
-2 & $2.6 \%$ & $6.1 \%$ & $10.5 \%$ \\
-1 & $2.6 \%$ & $12.7 \%$ & $24.4 \%$ \\
0 & $-23.1 \%$ & $19.3 \%$ & $43.8 \%$ \\
+1 & $-23.1 \%$ & $26.6 \%$ & $61.8 \%$ \\
+2 & $-23.1 \%$ & $34.3 \%$ & $79.2 \%$ \\
+3 & $-19.7 \%$ & $42.4 \%$ & $95.8 \%$ \\
\hline
\end{tabular}
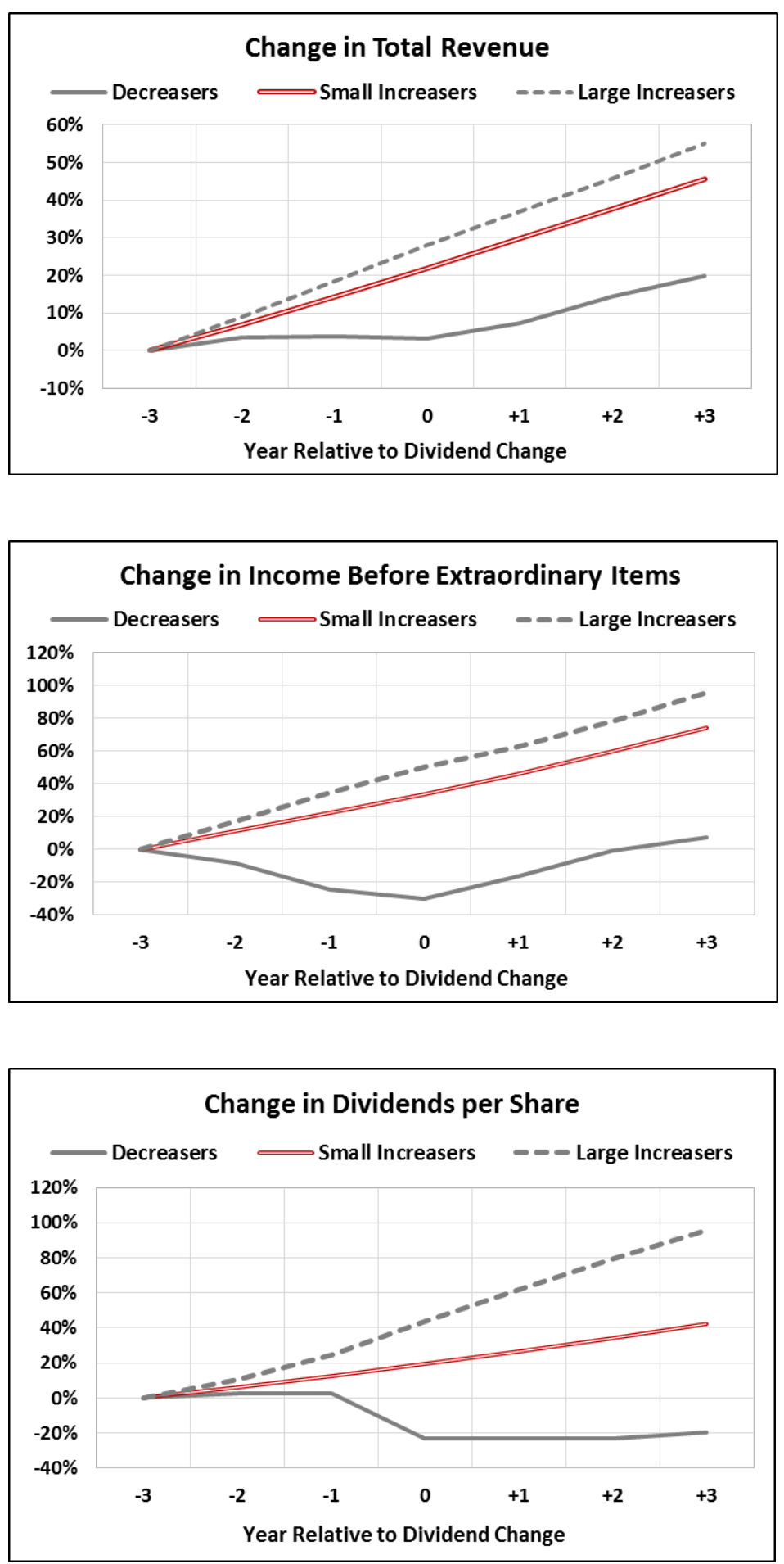
Table 2 (continued).

Panel D:

Change in Cash Flow

\begin{tabular}{cccc}
\hline Year & Decreasers & $\begin{array}{c}\text { Small } \\
\text { Increasers }\end{array}$ & $\begin{array}{c}\text { Large } \\
\text { Increasers }\end{array}$ \\
\hline-3 & $0.0 \%$ & $0.0 \%$ & $0.0 \%$ \\
-2 & $-4.1 \%$ & $4.1 \%$ & $10.0 \%$ \\
-1 & $-11.8 \%$ & $10.3 \%$ & $21.0 \%$ \\
0 & $-8.5 \%$ & $17.6 \%$ & $28.9 \%$ \\
+1 & $-11.9 \%$ & $26.1 \%$ & $38.7 \%$ \\
+2 & $-13.4 \%$ & $32.6 \%$ & $49.0 \%$ \\
+3 & $-8.5 \%$ & $38.2 \%$ & $58.0 \%$ \\
\hline
\end{tabular}

Panel E:

Change in Capital Expenditures

\begin{tabular}{cccc}
\hline Year & Decreasers & $\begin{array}{c}\text { Small } \\
\text { Increasers }\end{array}$ & $\begin{array}{c}\text { Large } \\
\text { Increasers }\end{array}$ \\
\hline-3 & $0.0 \%$ & $0.0 \%$ & $0.0 \%$ \\
-2 & $2.4 \%$ & $7.4 \%$ & $10.3 \%$ \\
-1 & $0.1 \%$ & $16.3 \%$ & $22.8 \%$ \\
0 & $-5.3 \%$ & $25.9 \%$ & $36.6 \%$ \\
+1 & $-2.0 \%$ & $34.8 \%$ & $48.1 \%$ \\
+2 & $7.4 \%$ & $43.7 \%$ & $55.8 \%$ \\
+3 & $14.0 \%$ & $49.3 \%$ & $63.3 \%$ \\
\hline
\end{tabular}

Panel F:

Change in SG\&A Expense

\begin{tabular}{cccc}
\hline Year & Decreasers & $\begin{array}{c}\text { Small } \\
\text { Increasers }\end{array}$ & $\begin{array}{c}\text { Large } \\
\text { Increasers }\end{array}$ \\
\hline-3 & $0.0 \%$ & $0.0 \%$ & $0.0 \%$ \\
-2 & $2.5 \%$ & $0.4 \%$ & $0.1 \%$ \\
-1 & $5.2 \%$ & $-0.3 \%$ & $0.3 \%$ \\
0 & $6.7 \%$ & $6.6 \%$ & $7.9 \%$ \\
+1 & $10.2 \%$ & $13.4 \%$ & $15.8 \%$ \\
+2 & $9.3 \%$ & $13.0 \%$ & $15.5 \%$ \\
+3 & $9.5 \%$ & $13.2 \%$ & $15.4 \%$ \\
\hline
\end{tabular}

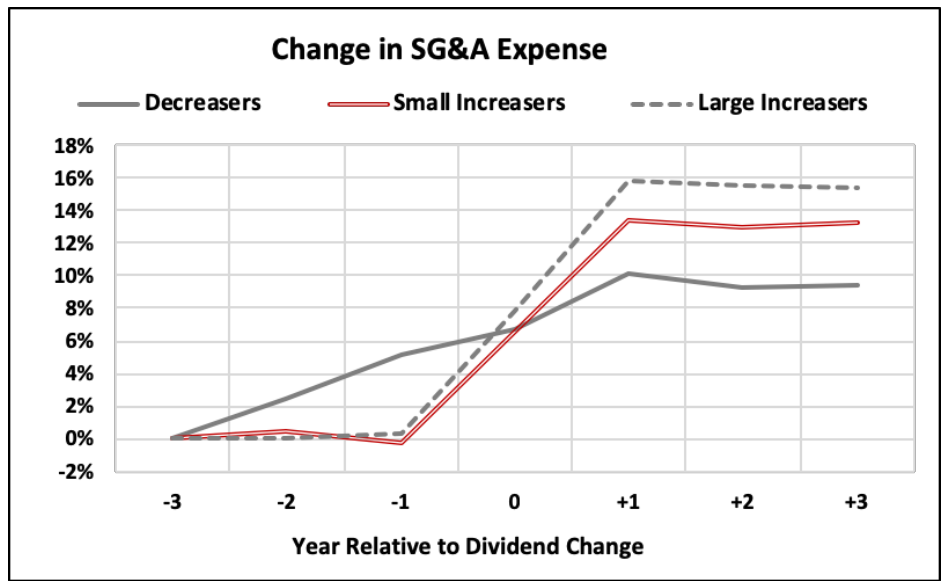


Table 3: Earnings Management Pre- and

Post-Dividend Change. This tables reports the median of various earnings management measures from years -3 to +3 relative to the year in which each dividend change event is announced. Firms are partitioned into 3 groups: dividend decreasers, small increasers, and large increasers. Large (small) increasers are firms with percentage changes in dividends above (below) the industry median for all firms increasing dividends. Variables are defined in Appendix A.

\section{Panel A:}

Median Total Abnormal Accruals (RACCR)

\begin{tabular}{crrr}
\hline Period & Decreasers & $\begin{array}{c}\text { Small } \\
\text { Increasers }\end{array}$ & $\begin{array}{c}\text { Large } \\
\text { Increasers }\end{array}$ \\
\hline-3 & $-2.17 \%$ & $-3.63 \%$ & $-3.37 \%$ \\
-2 & $-1.92 \%$ & $-3.24 \%$ & $-3.59 \%$ \\
-1 & $-1.14 \%$ & $-3.21 \%$ & $-3.60 \%$ \\
0 & $-2.36 \%$ & $-3.23 \%$ & $-3.54 \%$ \\
+1 & $-1.94 \%$ & $-3.53 \%$ & $-3.56 \%$ \\
+2 & $-2.08 \%$ & $-3.63 \%$ & $-3.68 \%$ \\
+3 & $-2.31 \%$ & $-3.70 \%$ & $-3.94 \%$ \\
\hline
\end{tabular}

Panel B:

\section{Median Abnormal SG\&A Expense (RSG)}

\begin{tabular}{crrr}
\hline Year & Decreasers & $\begin{array}{c}\text { Small } \\
\text { Increasers }\end{array}$ & $\begin{array}{c}\text { Large } \\
\text { Increasers }\end{array}$ \\
\hline-3 & $0.33 \%$ & $2.24 \%$ & $1.41 \%$ \\
-2 & $0.73 \%$ & $2.19 \%$ & $1.87 \%$ \\
-1 & $-0.45 \%$ & $2.34 \%$ & $1.91 \%$ \\
0 & $1.16 \%$ & $2.57 \%$ & $2.02 \%$ \\
+1 & $0.11 \%$ & $2.73 \%$ & $1.90 \%$ \\
+2 & $0.39 \%$ & $2.71 \%$ & $2.31 \%$ \\
+3 & $1.07 \%$ & $2.69 \%$ & $2.43 \%$ \\
\hline
\end{tabular}

Panel C:

Median Abnormal Production Expense (RPROD)

\begin{tabular}{crrr}
\hline Year & Decreasers & $\begin{array}{c}\text { Small } \\
\text { Increasers }\end{array}$ & $\begin{array}{c}\text { Large } \\
\text { Increasers }\end{array}$ \\
\hline-3 & $-9.03 \%$ & $-6.26 \%$ & $-6.32 \%$ \\
-2 & $-8.53 \%$ & $-6.89 \%$ & $-6.97 \%$ \\
-1 & $-6.07 \%$ & $-6.57 \%$ & $-6.88 \%$ \\
0 & $-6.10 \%$ & $-6.23 \%$ & $-6.81 \%$ \\
+1 & $-6.23 \%$ & $-6.60 \%$ & $-6.76 \%$ \\
+2 & $-6.82 \%$ & $-6.41 \%$ & $-6.65 \%$ \\
+3 & $-5.71 \%$ & $-6.52 \%$ & $-6.66 \%$ \\
\hline
\end{tabular}

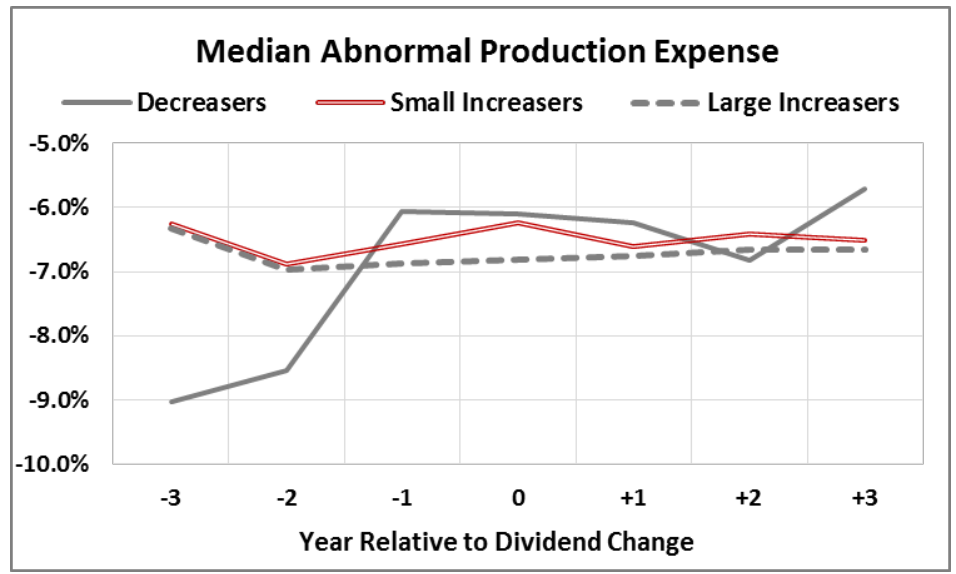


Table 3 (continued).

Panel D:

Median Total Real Earnings Management (REM)

\begin{tabular}{crrr} 
Year & Decreasers & $\begin{array}{c}\text { Small } \\
\text { Increasers }\end{array}$ & $\begin{array}{c}\text { Large } \\
\text { Increasers }\end{array}$ \\
\hline-3 & $-5.07 \%$ & $-3.78 \%$ & $-4.87 \%$ \\
-2 & $-6.34 \%$ & $-4.22 \%$ & $-4.56 \%$ \\
-1 & $-5.99 \%$ & $-3.56 \%$ & $-4.95 \%$ \\
0 & $-5.52 \%$ & $-2.81 \%$ & $-4.67 \%$ \\
+1 & $-6.96 \%$ & $-3.07 \%$ & $-4.26 \%$ \\
+2 & $-8.19 \%$ & $-3.05 \%$ & $-4.00 \%$ \\
+3 & $-3.23 \%$ & $-3.30 \%$ & $-3.00 \%$ \\
\hline
\end{tabular}

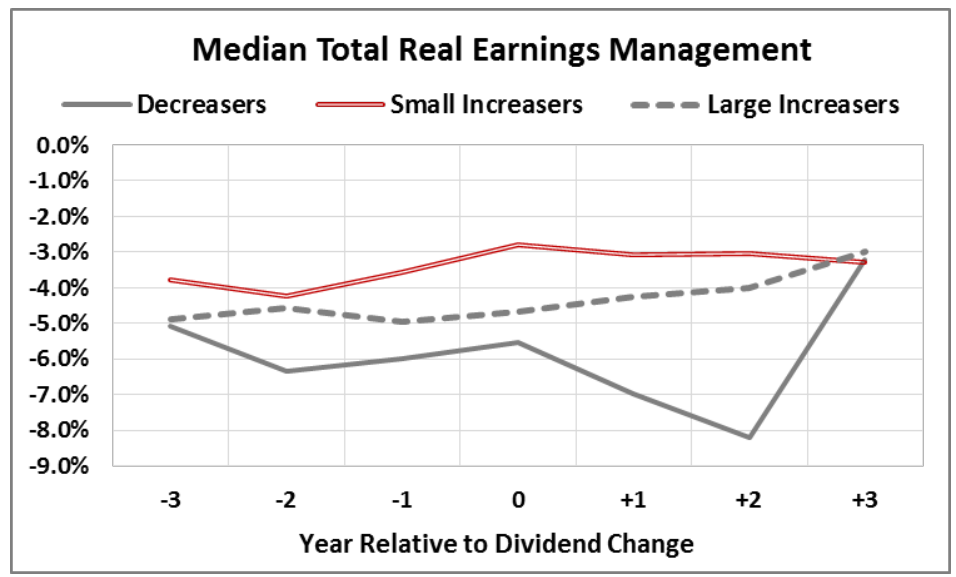


Table 4: Regressions of earnings management metrics on dividend change and control variables. This table reports the results of cross-sectional regressions of various earnings management metrics on the percentage change in a firm's annual dividend per share (\% ch. Div), the firm's most recent earnings surprise, and control variables:

$$
\begin{aligned}
& \text { Earnings Mngt. Proxy }=\beta_{0}+\beta_{1} \% \text { ch. Div }+\beta_{2} \text { Earnings Surprise }+\beta_{3} \text { Change in CFO }+ \\
& \beta_{4} \text { Change in Capital Spending }+\beta_{5} \text { SIZE }+\beta_{6} L E V+\beta_{7} C O M P+\beta_{8} I N S T O W N+\beta_{9} M / B+\beta_{10} L N(\text { age })+\varepsilon
\end{aligned}
$$

The earnings management metrics - RACCR (abnormal accruals), RSG (abnormal discretionary expenditures), RPROD (abnormal production costs) and REM (total real earnings management) - are the dependent variables in regression models 14. All variables are defined in Appendix A. Regression coefficients for variables significant at conventional levels ( $1 \%$ or $5 \%$ ) appear in bold.

\begin{tabular}{lrrrr}
\multicolumn{1}{c}{ Variable } & Model 1 & Model 2 & Model 3 & Model 4 \\
\hline RACCR & RSG & RPROD & REM \\
\hline Intercept & 0.0013 & 0.0083 & -0.0500 & -0.0417 \\
$t$-statistic & 0.13 & 0.34 & -1.83 & -0.85 \\
\% ch. Dividend & -0.0001 & $\mathbf{0 . 0 0 1 4}$ & $\mathbf{0 . 0 0 1 1}$ & $\mathbf{0 . 0 0 2 5}$ \\
$t$-statistic & -0.74 & 3.06 & 2.20 & 2.71 \\
Earnings Surprise & 0.0038 & 0.0123 & -0.0265 & -0.0142 \\
$t$-statistic & 0.29 & 0.42 & -0.74 & -0.23 \\
\% ch. Cash Flow & $\mathbf{- 0 . 0 0 0 2}$ & 0.0000 & 0.0000 & 0.0000 \\
$t$-statistic & -5.10 & 0.69 & -0.20 & 0.30 \\
\% ch. Capital Spending & 0.0000 & -0.0002 & 0.0001 & -0.0001 \\
$t$-statistic & 1.43 & -1.80 & 1.01 & -0.46 \\
SIZE & $\mathbf{- 0 . 0 0 4 5}$ & -0.0037 & $\mathbf{- 0 . 0 0 9 1}$ & $\mathbf{- 0 . 0 1 2 8}$ \\
$t$-statistic & -4.23 & -1.28 & -2.67 & -2.14 \\
LEV & $\mathbf{0 . 0 3 5 2}$ & 0.0073 & $\mathbf{0 . 0 9 3 2}$ & $\mathbf{0 . 1 0 0 5}$ \\
$t$-statistic & 3.98 & 0.32 & 3.76 & 2.23 \\
COMP & $\mathbf{- 0 . 0 0 0 3}$ & 0.0002 & 0.0001 & 0.0003 \\
$t$-statistic & -6.26 & 1.41 & 0.32 & 0.88 \\
INSTOWN & $\mathbf{- 0 . 0 1 7 0}$ & $\mathbf{0 . 0 5 9 0}$ & $\mathbf{0 . 0 5 8 2}$ & $\mathbf{0 . 1 1 7 1}$ \\
$t$-statistic & -2.33 & 2.78 & 2.60 & 2.81 \\
M/B & $\mathbf{- 0 . 0 0 3 9}$ & $\mathbf{- 0 . 0 1 0 9}$ & $\mathbf{- 0 . 0 2 3 2}$ & $\mathbf{- 0 . 0 3 4 1}$ \\
$t$-statistic & -6.15 & -7.37 & -10.34 & -9.58 \\
LN(age) & $\mathbf{0 . 0 0 7 7}$ & $\mathbf{0 . 0 1 2 6}$ & $\mathbf{0 . 0 2 3 7}$ & $\mathbf{0 . 0 3 6 3}$ \\
$t$-statistic & 3.57 & 2.23 & 3.90 & 3.24 \\
\hline $\boldsymbol{N} t$-Squared & 2581 & 2581 & 2581 & 2581 \\
Adjusted $\boldsymbol{R}$-Squared & $11.2 \%$ & $4.7 \%$ & $13.5 \%$ & $9.3 \%$ \\
\hline & $10.7 \%$ & $4.3 \%$ & $13.1 \%$ & $8.9 \%$ \\
\hline
\end{tabular}


Table 5: Logistic regressions estimating the probability that a firm will increase dividends. This table reports the results of logistic regressions estimating the probability that a firm will increase its dividend $(P A Y C H=1)$ as a function of earnings management metrics, the firm's most recent earnings surprise, and control variables:

$$
\begin{aligned}
\operatorname{Prob}(P A Y C H=1)= & \beta_{0}+\beta_{1} \text { Earnings Mngt. }+\beta_{2} \text { Earnings Surprise }+ \\
& \beta_{3} \text { Change in CFO }+\beta_{4} \text { Change in Capital Spending }+ \\
& \beta_{5} \text { SIZE }+\beta_{6} L E V+\beta_{7} C O M P+\beta_{8} \text { INSTOWN }+ \\
& \beta_{9} M / B+\beta_{10} L N(\text { age })+\varepsilon
\end{aligned}
$$

$R A C C R$ (abnormal total accruals), $R S G$ (abnormal discretionary expenditures), RPROD (abnormal production costs) and REM (total real earnings management) are the earnings management metrics in models 1-4. All variables are defined in Appendix A. Regression coefficients for variables significant at conventional levels (1\% or $5 \%)$ appear in bold.

\begin{tabular}{crrrr} 
& Model 1 & Model 2 & Model 3 & Model 4 \\
Variable & RACCR & RSG & RPROD & REM \\
\hline Intercept & 1.2173 & 1.2831 & 1.4188 & 1.3629 \\
$p$-value & 0.158 & 0.143 & 0.108 & 0.122 \\
Earnings Mngt. metric & -2.0885 & $\mathbf{1 . 9 2 9 3}$ & $\mathbf{1 . 9 9 7 3}$ & $\mathbf{1 . 0 7 2 4}$ \\
p-value & 0.302 & 0.008 & 0.005 & 0.004 \\
Earnings Surprise & 0.4527 & 0.4604 & 0.5111 & 0.4927 \\
$p$-value & 0.630 & 0.627 & 0.592 & 0.605 \\
\% ch. Cash Flow & -0.0001 & -0.0001 & 0.0002 & 0.0000 \\
$p$-value & 0.907 & 0.964 & 0.901 & 0.971 \\
\% ch. Capital Spending & $\mathbf{0 . 0 1 3 5}$ & $\mathbf{0 . 0 1 3 5}$ & $\mathbf{0 . 0 1 2 8}$ & $\mathbf{0 . 0 1 3 1}$ \\
$p$-value & $<.0001$ & $<.0001$ & 0.0001 & $<.0001$ \\
SIZE & $\mathbf{0 . 3 2 0 1}$ & $\mathbf{0 . 3 2 4 2}$ & $\mathbf{0 . 3 3 6 4}$ & $\mathbf{0 . 3 3 0 8}$ \\
$p$-value & 0.002 & 0.002 & 0.001 & 0.001 \\
LEV & $\mathbf{2 . 5 3 2 1}$ & $\mathbf{- 2 . 5 7 5 7}$ & $\mathbf{- 2 . 6 9 6 3}$ & $\mathbf{- 2 . 6 4 6 2}$ \\
$p$-value & 0.002 & 0.002 & 0.001 & 0.001 \\
COMP & 0.0060 & 0.0069 & 0.0068 & 0.0069 \\
$p$-value & 0.246 & 0.181 & 0.186 & 0.184 \\
INSTOWN & $\mathbf{1 . 3 3 3 9}$ & 1.2500 & 1.2430 & 1.2349 \\
$p$-value & 0.047 & 0.064 & 0.066 & 0.068 \\
M/B & 0.0586 & 0.0942 & 0.1273 & 0.1140 \\
$p$-value & 0.346 & 0.148 & 0.066 & 0.091 \\
LN(age) & -0.3924 & $\mathbf{- 0 . 4 3 5 2}$ & $\mathbf{- 0 . 4 7 0 5}$ & $\mathbf{- 0 . 4 5 6 7}$ \\
$p$-value & 0.065 & 0.045 & 0.032 & 0.037 \\
\hline $\boldsymbol{N}$ & 2581 & 2581 & 2581 & 2581 \\
Wald Ratio & 61.9 & 67.8 & 68.6 & 68.8 \\
$p$-value & $<.0001$ & $<.0001$ & $<.0001$ & $<.0001$ \\
\hline & & & & \\
\hline & & & & \\
& & & &
\end{tabular}


Table 6: Odds ratios and probabilities from logistic regressions. This table reports the odds ratios $\left(O R=\frac{P}{1-p}\right)$ and probabilities $(p)$ calculated based on the logit regressions shown as Equation 5 and reported in Table 5:

$$
\begin{aligned}
\operatorname{Prob}(\text { PAYCH }=1)= & \beta_{0}+\beta_{1} \text { Earnings Mngt. }+\beta_{2} \text { Earnings Surprise }+ \\
& \beta_{3} \text { Change in CFO }+\beta_{4} \text { Change in Capital Spending }+ \\
& \beta_{5} \text { SIZE }+\beta_{6} L E V+\beta_{7} C O M P+\beta_{8} \text { INSTOWN }+ \\
& \beta_{9} M / B+\beta_{10} L N(\text { age })+\varepsilon
\end{aligned}
$$

$R A C C R$ (abnormal total accruals), $R S G$ (abnormal discretionary expenditures), RPROD (abnormal production costs) and REM (total real earnings management) are the earnings management metrics in models 1-4. All variables are defined in Appendix A. Probabilities for variables significant at conventional levels from the estimation of Equation $5(1 \%$ or $5 \%)$ appear in bold.

\begin{tabular}{lrrrr} 
& Model 1 & Model 2 & Model 3 & Model 4 \\
Variable & RACCR & RSG & RPROD & REM \\
\hline Earnings Mngt. metric & 0.1239 & 6.8847 & 7.3691 & 2.9224 \\
Probability & 0.110 & $\mathbf{0 . 8 7 3}$ & $\mathbf{0 . 8 8 1}$ & $\mathbf{0 . 7 4 5}$ \\
Earnings Surprise & 1.573 & 1.5847 & 1.6671 & 1.6367 \\
Probability & 0.6113 & 0.613 & 0.625 & 0.621 \\
\% ch. Cash Flow & 0.9999 & 0.9999 & 1.0002 & 1.0000 \\
Probability & 0.500 & 0.500 & 0.500 & 0.500 \\
\% ch. Capital Spending & 1.0136 & 1.0136 & 1.0129 & 1.0132 \\
Probability & $\mathbf{0 . 5 0 3}$ & $\mathbf{0 . 5 0 3}$ & $\mathbf{0 . 5 0 3}$ & $\mathbf{0 . 5 0 3}$ \\
SIZE & 1.3773 & 1.3829 & 1.3999 & 1.3921 \\
Probability & $\mathbf{0 . 5 7 9}$ & $\mathbf{0 . 5 8 0}$ & $\mathbf{0 . 5 8 3}$ & $\mathbf{0 . 5 8 2}$ \\
LEV & 0.0795 & 0.0761 & 0.0675 & 0.0709 \\
Probability & $\mathbf{0 . 0 7 4}$ & $\mathbf{0 . 0 7 1}$ & $\mathbf{0 . 0 6 3}$ & $\mathbf{0 . 0 6 6}$ \\
COMP & 1.0060 & 1.0069 & 1.0069 & 1.0069 \\
Probability & 0.502 & 0.502 & 0.502 & 0.502 \\
INSTOWN & 3.7958 & 3.4903 & 3.4660 & 3.4380 \\
Probability & $\mathbf{0 . 7 9 2}$ & 0.773 & 0.776 & 0.775 \\
M/B & 1.0604 & 1.0988 & 1.1358 & 1.1208 \\
Probability & 0.515 & 0.523 & 0.532 & 0.529 \\
LN(age) & 0.6754 & 0.6471 & 0.6247 & 0.6333 \\
Probability & 0.403 & $\mathbf{0 . 3 9 3}$ & $\mathbf{0 . 3 8 5}$ & $\mathbf{0 . 3 8 8}$ \\
\hline $\boldsymbol{N}$ & 2581 & 2581 & 2581 & 2581 \\
\hline
\end{tabular}


Table 7: This table reports the results of cross-sectional regressions of the three-day cumulative abnormal returns around the dividend change announcement date (days -1 to +1 ) on each earnings management metric, the percentage change in firms' annual dividend per share (\% ch. Div) and control variables.

$$
\begin{aligned}
& \text { CAR }_{3}=\beta_{0}+\beta_{1} \% \text { ch. Div }+\beta_{2} \text { Earnings Mngt. }+\beta_{3} \text { Change in CFO }+\beta_{4} \text { Change in Capital Spending }+ \\
& \beta_{5} \text { SIZE }+\beta_{6} L E V+\beta_{7} C O M P+\beta_{8} \text { INSTOWN }+\beta_{9} M / B+\beta_{10} L N(\text { age })+\varepsilon
\end{aligned}
$$

$R A C C R$ (abnormal total accruals), RSG (abnormal discretionary expenditures), RPROD (abnormal production costs) and REM (total real earnings management) are the earnings management metrics in models 1-4. All variables are defined in Appendix

\begin{tabular}{|c|c|c|c|c|}
\hline Variable & $\begin{array}{l}\text { Model 1 } \\
\text { RACCR } \\
\end{array}$ & $\begin{array}{r}\text { Model } 2 \\
\text { RSG } \\
\end{array}$ & $\begin{array}{l}\text { Model } 3 \\
\text { RPROD } \\
\end{array}$ & $\begin{array}{r}\text { Model } 4 \\
\text { REM } \\
\end{array}$ \\
\hline Intercept & 0.0040 & 0.0040 & 0.0043 & 0.0041 \\
\hline$t$-statistic & 0.71 & 0.71 & 0.76 & 0.73 \\
\hline$\%$ ch. Dividend & 0.0004 & 0.0004 & 0.0004 & 0.0004 \\
\hline$t$-statistic & 3.14 & 3.08 & 3.08 & 3.07 \\
\hline Earnings Mngt. metric & 0.0006 & 0.0035 & 0.0054 & 0.0025 \\
\hline$t$-statistic & 0.05 & 0.79 & 1.34 & 1.13 \\
\hline$\%$ ch. Cash Flow & 0.0000 & 0.0000 & 0.0000 & 0.0000 \\
\hline$t$-statistic & 1.11 & 1.12 & 1.13 & 1.12 \\
\hline$\%$ ch. Capital Spending & 0.0000 & 0.0000 & 0.0000 & 0.0000 \\
\hline$t$-statistic & 1.03 & 1.06 & 1.00 & 1.04 \\
\hline SIZE & 0.0004 & 0.0004 & 0.0004 & 0.0004 \\
\hline$t$-statistic & 0.56 & 0.58 & 0.64 & 0.61 \\
\hline LEV & -0.0094 & -0.0095 & -0.0099 & -0.0097 \\
\hline$t$-statistic & -1.72 & -1.73 & -1.82 & -1.77 \\
\hline COMP & 0.0000 & 0.0000 & 0.0000 & 0.0000 \\
\hline$t$-statistic & 1.4 & 1.42 & 1.4 & 1.39 \\
\hline INSTOWN & -0.0047 & -0.0049 & -0.0050 & -0.0050 \\
\hline$t$-statistic & -1.02 & -1.06 & -1.09 & -1.08 \\
\hline $\mathbf{M} / \mathbf{B}$ & 0.0002 & 0.0002 & 0.0003 & 0.0003 \\
\hline$t$-statistic & 0.74 & 0.87 & 1.13 & 1.01 \\
\hline LN(age) & -0.0005 & -0.0005 & -0.0006 & -0.0006 \\
\hline$t$-statistic & -0.38 & -0.41 & -0.47 & -0.44 \\
\hline$N$ & 2581 & 2581 & 2581 & 2581 \\
\hline$R$-Squared & $1.3 \%$ & $1.3 \%$ & $1.4 \%$ & $1.3 \%$ \\
\hline Adjusted $R$-Squared & $0.9 \%$ & $0.9 \%$ & $1.0 \%$ & $1.0 \%$ \\
\hline
\end{tabular}
A. Regression coefficients for variables significant at conventional levels (1\% or $5 \%)$ appear in bold. 